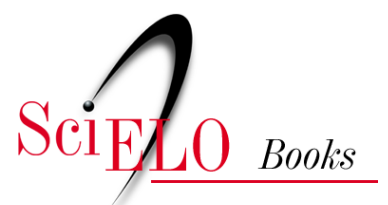

\title{
Da compaixão à solidariedade: uma genealogia da assistência médica
}

\author{
Sandra Caponi
}

\section{SciELO Books / SciELO Livros / SciELO Libros}

CAPONI, S. Da compaixão à solidariedade: uma genealogia da assistência médica [online]. Rio de Janeiro: Editora FIOCRUZ, 2000. ISBN: 978-85-7541-515-3. Available from: doi:

10.7476/9788575415153. Also available in ePUB from: http://books.scielo.org/id/dg2mj/epub/caponi9788575415153.epub

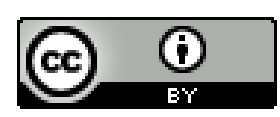

All the contents of this work, except where otherwise noted, is licensed under a Creative Commons Attribution 4.0 International license.

Todo o conteúdo deste trabalho, exceto quando houver ressalva, é publicado sob a licença $\underline{\text { Creative Commons }}$ Atribição 4.0.

Todo el contenido de esta obra, excepto donde se indique lo contrario, está bajo licencia de la licencia $\underline{\text { Creative }}$ Commons Reconocimento 4.0. 
SANDRA CAPONI

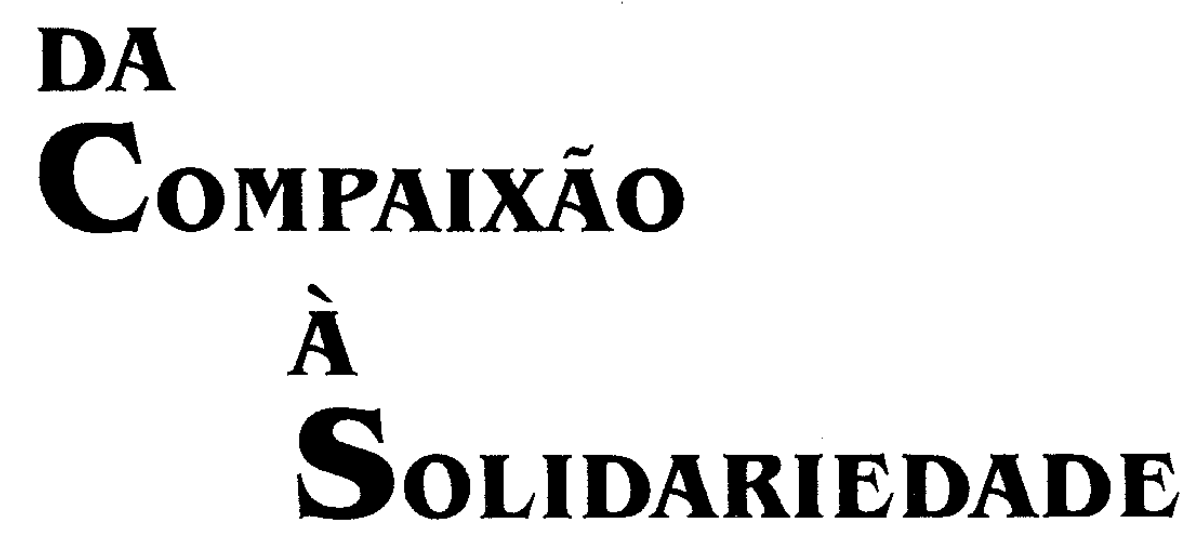

uma genealogia da assistência médica 
Copyright (c) 2000 by Sandra Caponi

Todos os direitos desta edição reservados à

FLNDAÇÃO OSWALDO CRUZ / EDITORA

ISBN: 85-85676-88-4

Capa, Projeto Gráfico: Carlota Rios

Ilustração da Capa: a partir da pintura Morte e Vida de Gustav Klimt - 1908.

Editoração Eletrônica: Ramon Carlos de Moraes

Copidesque, Preparação de Originais e Revisão: Fernanda Veneu

Supervisão Editorial: M. Cecilia Gomes Barbosa Moreira

Catalogação na fonte

Centro de Informação Científica e Tecnológica

Biblioteca Lincoln de Freitas Filho

C246c Caponi, Sandra

Da compaixão à solidariedade: uma genealogia da assistêncià médica. / Sandra Caponi. - Rio de Janeiro : Editora FIOCRUZ, 2000.

$100 \mathrm{p}$.

1. Assistência médica-história. 2. Justiça social-história. 3. Filosofia médica.

CDD - 20.ed. - 614.44

\section{EDITORA FIOCRUZ}

Rua Leopoldo Bulhões, 1480, térreo - Manguinhos

21041-210 - Rio de Janeiro - RJ

Tels: (21) 598-2701/598-2702

Fax: (21) 598-2509 
A Gustavo e Mauro 


\section{SumárI0}

APRESENTAÇÃO

1. A LÓGICA DA COMPAIXÃO 15

2. O OLHAR MÉDICO E A TECNOLOGIA PASTORAL

3. DISCIPLINA E FILANTROPIA

CONCLUSÃO

91

REFERÊNCIAS BIBLIOGRÁFICAS 


\section{Apresentação}

$\mathrm{O}$

compromisso com a pessoa que sofre pode ter as mais diversas motivações. Pode resultar da solidariedade genuína, do respeito mútuo, do reconhecimento de que algo semelhante pode nos acontecer. Pode resultar, também, de um sentimento de 'compaixão piedosa' pelos sofredores através do qual acreditamos tornarmo-nos benfeitores virtuosos. Pode, por fim, ocorrer, simplesmente, porque pensamos que socorrer aos infortunados contribui para o bem comum e para o bem-estar geral.

$O$ presente trabalho tem o objetivo de problematizar as motivações que fundamentaram duas modalidades diversas de intervenção sobre a saúde das populações no transcurso do século XIX. Trata-se de duas estratégias diferenciadas de assistência à sociedade que, no entanto, como tentaremos mostrar, não são inteiramente alheias uma à outra, embora assim se apresentem.

Na primeira parte analisaremos o papel desempenhado por uma ética da compaixão na constituição e legitimação daquelas modalidades de assistência que, nas últimas décadas do século XVIII, deram lugar à chamada 'época da bondade'. Esta problematização da ética da compaixão exigirá uma referência ao pensamento de Rousseau e a sua insistência em dar prioridade à piedade - que aproxima os doentes e os cuidadores na imediatez do sentimento compartilhado - sobre a frieza das intervenções racionalmente fundamentadas. Empreender uma critica às intervenções assistenciais fundamentadas na piedade e na compaixão exigirá que recorramos às análises de Frederico Nietzsche e de Hannah Arendt. Ambos souberam assinalar os limites e os riscos políticos implicados nessas intervenções que se definem como 'compassivas'. 
Porém, a segunda modalidade de assistência antes mencionada será analisada na terceira parte deste trabalho. Tematizaremos esse utilitarismo difuso e generalizado que permeia e sustenta os diversos tipos de intervenções assistenciais próprios das políticas filantrópicas do século XIX. Deter-nos-emos na análise do pensamento de Bentham por considerar que sua formulação do utilitarismo é a que melhor traduz essa perspectiva.

Certamente o utilitarismo contemporâneo, e até o próprio Stuart Mill, introduziram mudanças que nos impedem de generalizar as observações aqui expostas. No entanto, no que diz respeito à perspectiva benthamiana, pode-se afirmar sua indissolúvel vinculação com as políticas filantrópicas que delinearam o perfil da assistência à saúde da comunidade no século XIX. Neste caso, e tomando como ponto de partida as críticas de MacIntyre e Rawls, procuraremos assinalar as dificuldades envolvidas na fundamentação utilitarista das intervenções assistenciais.

No entanto, nosso objetivo é mostrar, a partir da análise de práticas e de estratégias pontuais de assistência, que vão da lei de pobres à medicalização da família, que não existe uma ruptura absoluta, mas sim continuidade, solidariedade e complementaridade entre as políticas assistenciais fundadas em uma ética compassiva, e aquelas fundadas no utilitarismo clássico. Tal continuidade manifesta-se ainda que estas últimas se apresentem como a garantia de ruptura e de superação das insuficiências das primeiras.

É na segunda parte deste estudo que essa complementaridade se evidencia. Centrar-nos-emos, aqui, nos trabalhos de Michel Foucault. Fazendo uma leitura retrospectiva de seus escritos, acreditamos que é possível afirmar que, na emergência da clínica, do hospital medicalizado e na medicina social, convivem, sem maiores dificuldades, estratégias de poder pastoral (próximas à compaixão piedosa) com estratégias de organização dos espaços e de controle do tempo próprias da sociedade disciplinar e das intervenções políticas fundamentadas no utilitarismo.

Em resumo: pretendemos empreender uma cartografia dessas práticas assistenciais que tomaram por objeto a saúde das populações, tentando assinalar continuidades e rupturas, olhando para os limites éticos e políticos dessas estratégias. Pois, justamente no momento em 
que elas dizem auxiliar, parecem reforçar formas coercivas de controle, seja em nome da utilidade e da felicidade do maior número, seja em nome de uma piedade compassiva pelos que sofrem.

Se voltamos para os séculos XVIII e XIX, é porque acreditamos, junto com Foucault e com Rosen, que uma análise crítica do modelo histórico de funcionamento da medicina e da assistência pode nos auxiliar a pensar, de outro modo, na sua existência atual, assim como na procura de alternativas para projetar como podem ser modificadas. Trata-se, pois, de fazer um uso estratégico da história, de usar essas análises genealógicas com o olhar direcionado para o presente, com o objetivo de contribuir para criticar e transformar a assistência médica que ainda hoje, e em muitos casos, parece não poder prescindir da vigilância e do controle para efetivar-se. Neste sentido, gostaríamos de fazer nossas estas palavras de Roberto Machado (1978:12):

Uma dupla relação se estabelece entre a história e a atualidade: por um lado, o desvelamento do passado, do modo específico de emergência das configurações atuais, é indispensável para uma percepção mais lúcida do presente. No momento em que se procuram novas formas de funcionamento da medicina que não veiculem uma dominação de classe, que não sejam uma intensificação dos dispositivos de poder criados pelo capitalismo como condição indispensável à sua perpetuação, a abordagem crítica da história é um instrumento importante para a realização das experiências que pretendem impregnar o futuro. Por outro lado, a ida ao passado, o projeto de pesquisar as origens da (...) medicina como discurso e como prática política, é, ele próprio esclarecido pelo presente, determinado pela exigência de aprofundar sua crítica e de fornecer elementos para a transformação das condições atuais de seu modo de intervenção.

Para compreender por que se fala aqui de necessidade de transformação dos modos atuais de intervenção, é preciso considerar essas estratégias de poder que no dia-a-dia percorrem o âmbito dos saberes médico-corretivos. Elas nos situam perante conflitos éticos urgentes que, longe de emergir sob circunstâncias excepcionais e limites, definem a maior parte de nosso cotidiano. Estas estratégias de 'biopoder' interferem em nossa existência, na medida em que cuidam de nossa saúde, vigiam nossos movimentos, discutem nossa sexualidade, admi- 
nistram nossa força de trabalho e assistem nossas necessidades mais elementares, olhando para os aspectos mais ínfimos e as tramas mais íntimas de nossa vida. Se isto é possível, é porque em cada um desses espaços, as tecnologias médicas apontam para a dimensão do humano que mais nos aproxima de uma coisa manipulável: nosso corpo.

Mas, para que este controle possa ser aceito, para que ele possa ser entendido e até exigido, é mister que se apresente sob a forma, dificilmente objetável, de uma compaixão piedosa para com as pessoas que estão, atual ou virtualmente, em posição de inferioridade: aqueles que precisam ser assistidos. Acreditamos que é fundamental problematizar o fato de que, quase invariavelmente, a assistência compulsiva encontra sua justificativa e se faz aceitável ou por referência a um sentimento de piedade pelos necessitados e pelos sofredores, ou pela afirmação de que esse controle obedece a demandas claras de utilidade, de urgência social ou de bem-estar geral.

Quiçá seja Michel Foucault quem mais se deteve na problematização desses conflitos que parecem ser inerentes ao 'saber médico'. Para ele, hoje estamos assistindo a uma extensão abusiva do que pode ser pensado como 'medicalizável', e isto deriva-se de nossa dificuldade para demarcar os limites desses conceitos ambíguos que são os de 'normalidade', 'saúde', 'patologia' e 'doença'. Faz tempo que assistimos a uma expansão progressiva das consideradas patologias, às quais, portanto, acreditamos que é lícito assistir medicamente. Ao dizer 'medicamente', referimo-nos não só à intervenção direta de médicos e de enfermeiras, mas também às intromissões não solicitadas, desse conjunto de experts em assistência formado por psicólogos, psiquiatras, assistentes sociais e educadores, sempre que a 'sensibilidade social' ou alguma 'cruel compaixão' assim o exijam.

Sabemos que, para que o poder seja aceito, é mister que ele possa gerar, produzir positividades. $O$ poder não possui exclusivamente a força do 'não'; ele detém uma capacidade produtiva, produz saber, produz individualidades e subjetividades, e nos produz como os seres que somos. Essa capacidade produtiva está claramente evidenciada no saber médico, que faz sua aparição justamente ali onde se demandam a cura, o cuidado e a assistência. Justamente nestas circunstâncias limites, nas quais parece 
que nos encontramos literalmente nas mãos de outro, de um outro no qual é preciso confiar quase que cegamente.

Mas, certamente, a capacidade de aliviar o sofrimento, de cuidar, assistir e curar não implica, de modo necessário ou tautológico, aceitar essas intromissões coercivas que podem vir a ser exercidas precisamente no momento em que se torna efetiva a assistência. Intromissões que invariavelmente são realizadas em nome e pelo bem daquele que está sendo assistido. Interessa-nos tematizar a modalidade que adota esta forma de coerção. Acreditamos ser possível afirmar que o que, historicamente, fez com que tal coerção fosse tolerada é o fato de que ela sempre gostou de se apresentar sob a forma do humanismo, da compaixão piedosa, ou da utilidade e do bem-estar do maior número.

É mister sublinhar que não pretendemos aqui retirar, finalmente, este véu que tem a forma da piedade ou da felicidade geral, para poder mostrar, assim, em toda sua crueldade, a verdade nua da coerção e da hipocrisia. Isto é, não pretendemos desmascarar uma ideologia por trás da qual o controle social gosta de se apresentar. Muito pelo contrário, nosso interesse é tematizar a própria compaixão piedosa e a própria ética utilitarista como estratégias de poder que, originariamente, e pela sua própria lógica, reproduzem e afirmam um tipo de racionalidade fundada em distinções subordinantes, que excluem e anulam a existência de vínculos legítimos entre iguais.

Trata-se, em resumo, de analisar os mecanismos e a 'razão de ser' dessa vinculação (não enunciada nem admitida) entre poder disciplinar e compaixão piedosa, que ainda se evidencia em algumas de nossas instituições e práticas assistenciais. Pretendemos refletir sobre os limites dessas estratégias com a finalidade de repensar nossas políticas assistenciais desde uma perspectiva divergente tanto do utilitarismo difuso que permeia a assistência filantrópica, quanto da compaixão piedosa que sustenta a caridade. Acreditamos que é preciso pensar essas políticas a partit da solidariedade, do respeito e do mútuo reconhecimento. Quiçá, então, se possam fortalecer os necessitados, em lugar de debilitá-los; possibilitar sua inserção em novas redes sociais, e não estimular seu isolamento; reconhecer neles sujeitos capazes de decisão e diálogo, e não reforçar estratégias de infantilização. 


\section{A LógICA da Compaixão}

Existia, para a mulher consagrada - a dama de caridade que precede a enfermeira profissional -, um estatuto quase sagrado. Elas eram reconhecidas como portadoras de dons divinos pelos seus atos, suas esmolas, sua assistência, o que as tornava benfeitoras. Existia, também, um estatuto social dos pobres de Deus por elas assistidos: eles deveriam estar permanentemente em dívida pelo bem recebido. Seu papel era o da eterna gratidão, pois eles representavam a impossibilidade, a incapacidade de se situarem "numa relação de paridade e de poder participar de relações sociais que exijam julgamento e discernimento" (Collière, 1989:69).

Que obscuros mecanismos nos levam a acreditar que existe nessa relação - que pressupõe a desigualdade, a dívida e a gratidão - um vínculo moralmente legítimo ou desejável? Ainda que nenhum benfeitor tolere reconhecer-se na imagem da mulher consagrada, existe algo dessa piedade compassiva que, sob formas diversas, percorre muitas das diferentes estratégias assistenciais que historicamente se sucederam.

A partir de Florence Nightingale, a mulher consagrada será substituída pela enfermeira profissional. Ela deixará de possuir um caráter religioso, porém não deixará de pensar a assistência prestada como um vínculo que supõe e reforça a submissão. Segundo Lunardi (1998:124):

Supõe-se que a enfermeira está presente a fim de evitar que o doente faça esforço físico - eu diria que ela está lá para evitar que ele tome suas próprias decisões. Estou certa de que, se for evitado que o paciente decida por si mesmo, ainda que não seja poupado de todo esforço físico, ele sairá sempre ganhando.

Para responder à pergunta enunciada, é necessário problematizar a lógica interna da compaixão piedosa. Como tentaremos mostrar, ela 
parece instaurar uma modalidade peculiar de exercício de poder que se estrutura a partir do binômio servir-obedecer, multiplicando, assim, a existência de relações dissimétricas, entre quem assiste e quem é assistido. Se acreditamos que é necessário excluir do discurso médico a caridade cristã e a piedade religiosa, aquela que costumava situar o doente no lugar da debilidade mais absoluta e da mais extrema impotência, então será mister que se desenvolvam, onde hoje existe aceitação passiva, estratégias capazes de fazer que a palavra dos doentes possa fazer parte de uma rede dialógica, que permita instituir um genuíno consenso. Mas, para que este objetivo seja atingido, é preciso analisar a estrutura e o modo de funcionamento dessa compaixão piedosa.

Empreender uma crítica da ética da caridade e da compaixão exige que nos lembremos de Nietzsche, pois é mérito seu ter sabido iniciar, com lucidez e firmeza, um estudo demolidor das estratégias de poder que, no preciso momento em que nos prometem auxílio e assistência, multiplicam os mecanismos de coerção, docilização e submissão.

As perguntas que Nietzsche (1984:\$338) faz a respeito da caridade e da compaixão podem ser resumidas em duas: "É conveniente ser, antes de mais nada, homens compassivos?" e "É conveniente para os que padecem que deles vos compadeçais?". A resposta a esta questão será clara: "Nossos benfeitores diminuem nosso valor e nossa vontade, ainda mais que nossos próprios inimigos".

O que acontece é que esses benfeitores estão impossibilitados de interpretar corretamente, em toda a complexidade, a dor de quem padece - uma característica que define o compassivo: "pois o próprio do sentimento de compaixão é despojar a dor alheia do que ela tem de pessoal", de individual, de único e irredutível. Quando o sentimento de piedade pretende superar o limite da individualidade, se faz intolerável. Por isso é que "na maior parte dos bencfícios aos necessitados existe algo que indigna, pela indiferença intelectual com que o compassivo julga o destino, sem saber nada das conseqüências e complicações interiores que, para mim e para você, se chamam infortúnio" (Nietzsche, 1984:\$338).

A pessoa compassiva tem o impulso de socorrer, quanto antes melhor, sem avaliar se as conseqüências do socorro imediato são ou não desejadas por aquele que padece um infortúnio. Para Nietzsche 
(1984:\$338), a figura do homem piedoso é alguém que não pode tolerar qualquer tipo de dor, por menor que seja, que não pode desfrutar ou aprender com a sua solidão, é alguém que "quer socorrer e não pensa que o infortúnio pode ser uma necessidade pessoal e que você e eu podemos necessitar tanto do terror, das privações, da pobreza, das aventuras, dos perigos, dos desenganos quanto dos bens contrários". Enfim, trata-se de alguém cuja única religião não é a caridade, pois ele professa também a "religião do bem-estar", ficando assim impossibilitado de entender aqueles para os quais o bem-estar, seja real ou possível, longe de representar um valor, constitui uma ameaça, algo como a calma que precede o nada.

No momento em que a saúde pode ser pensada em termos de bemestar (físico, psíquico ou social), este passa a ser considerado como valor. Então, pensamos que é próprio do âmbito da saúde tudo aquilo que, em uma determinada sociedade e em um determinado momento histórico, tem de ser qualificado de modo positivo (o que produz ou que deveria produzir uma sensação de bem-estar): a laboriosidade, a convivência social, a vida familiar, o controle dos excessos. E, assim, será pensado como contravalor, como seu reverso patológico e passível de assistência, tudo aquilo que possa ser considerado perigoso ou não desejado.

Porém, não se pode esquecer que os infortúnios, as infidelidades, o mal-estar fazem parte da existência. Como afirma Canguilhem, nosso mundo é um mundo de acidentes possíveis, de infidelidades e de fracassos. A dificuldade de integrar o mal-estar ao conceito de saúde, isto é, a dificuldade de encontar um conceito capaz de integrar as variações, ${ }^{1}$ as anomalias e os infortúnios tem levado a ampliar, cada vez mais, o âmbito de ingerência da assistência médica. "É aqui que certo discurso acha sua justificativa. Esse discurso é o da Higiene, disciplina médica tradicional, recuperada e disfarçada por uma ambição sócio-político-médica de regulamentação da vida dos indivíduos" (Canguilhem, 1990:37).

É por isso que cotidianamente podemos assistir a imorais, mas piedosas, atitudes que, respondendo à força da compaixão e à procura do bem-estar, reproduzem a mais ilegítima - ainda que legalizada - coerção: aquela que pessoas caridosas exercem sobre os infortunados. Legi-

\footnotetext{
' Esta questāo é analisada em Caponi (1996).
} 
tima-se assim que, compulsoriamente, os 'sem-teto' sejam deslocados para abrigos públicos reconhecidamente perigosos; admite-se que os ditos 'loucos' sejam isolados em centros que, indiscutivelmente, não são espaços de reabilitação ou cura; estimula-se que os 'meninos de rua’ sejam recolhidos em asilos para esperar uma adoção sempre diferida; interfere-se, piedosamente, na dissolução e separação de famílias carentes. As reflexões de Nietzsche, assim como as de Hannah Arendt e Thomas Szasz, se defrontam com esses mecanismos obscuros e cotidianos, através dos quais a piedade e a compaixão se revelam como uma perigosa e temível tecnologia de poder que, no entanto, insiste em aparecer sob a forma de um desapaixonado e necessário 'humanismo'.

É provável que descubramos a existência desses espetáculos de coerção e submissão. Porém, essa freqüência nada nos diz a respeito dos motivos que levam esses homens e mulheres benfeitores a compartilhar a crença de que, por trás das inclinações caridosas, estão realizando atos morais. Além disso, por meio dessas realizações, eles poderão converter-se e afirmar-se como pessoas virtuosas. É preciso descartar a existência de um maquiavelismo consciente que prefere se apresentar como compassivo para poder exercer assim, mais livremente, o domínio e o poder. Talvez os motivos sejam mais simples, e é outra vez em Nietzsche que devemos procurar alguma resposta à pergunta sobre a conveniência em sermos compassivos.

Veremos então que as conveniências são múltiplas:

O contratempo sofrido por outra pessoa nos ofende, nos faz sentir nossa impotência e talvez nossa covardia, se não acudirmos em seu auxílio. Ou, então, na dor alheia vemos algum perigo que também nos ameaça, ainda que sejam somente sinais da insegurança e da fragilidade humanas, os infortúnios alheios podem produzir em nós penosos efeitos. Rejeitamos esse gênero de ameaça e de dor e lhe respondemos por meio de um ato de compaixão, no qual pode existir uma sutil defesa de nós mesmos e até algum resquício de vingança. (Nietzsche, 1981:\$133)

Em todos esses e outros fenômenos que se resumem na palavra 'caridade', o que se evidencia é que, na realidade, "pensamos muito mais em nós mesmos que nos outros" (Nietzsche, 1981:\$133). O que fazemos no momento de realizar um ato de caridade é libertar-nos 
de um sentimento de dor que é absolutamente nosso, a dor que inspira o espetáculo da miséria, e o que fazemos, então, é libertar-nos desse padecimento.

Tomas Szasz dá um bom exemplo de que como não há razão para considerar a compaixão uma virtude. Ao narrar suas lembranças de Budapeste, a visão de amputados e indigentes, solicitando algumas moedas, lembra esse sentimento de compaixão que então se apoderava dele:

Nesse ínterim, dei-me conta de que minha generosidade não era totalmente altruísta, que eu era motivado por um vago receio de que um destino semelhante pudesse recair sobre mim, aliado a uma esperança supersticiosa de que minha oferta pudesse evocar uma divindade com poderes misteriosos sobre esses assuntos. (Szasz, 1994:22)

$\mathrm{Na}$ verdade, o problema aparece quando elevamos essa compaixão - que sabemos inútil e ineficiente, que reconhecemos como um pobre instrumento para suprir qualquer necessidade - ao nível de uma categoria moral ou social, quando acreditamos que é capaz e eficiente a ponto de nos construir como agentes 'morais', ou quando pretendemos fundamentar nela uma ordem social justa. Esquecemos que a justiça só pode ser compreendida conjuntamente com a eqüidade e a imparcialidade. $\mathrm{E}$ que as diferenças que o compassivo reforça dificilmente podem produzir relações fundadas na eqüidade, até pela simples razão de que a compaixão não tem por objetivo transformar as condições materiais que conduzem à desigualdade.

O que está em jogo aí é a lógica interna da moral da compaixão. Uma lógica que, como já foi dito, pode e deve ser analisada como a racionalidade própria de uma estratégia de poder. Como afirma Nietzsche (1978:\$133),

ao realizar atos de caridade o que fazemos é libertar-nos de um padecimento que é nosso. No entanto, não agimos nessa direção impulsionados por um único motivo, e ainda quando seja verdade que queremos nos libertar de uma dor, também é verdade que agimos impulsionados pelo júbilo provocado pelo espetáculo de uma situação oposta à nossa, pela idéia de poder socorrer aquele infortunado se assim o desejarmos, pela esperança da gratidão que haveremos de obter pela atividade do socorro. 
Ainda que nos horrorizemos perante a idéia desse júbilo, não é outra coisa que se evidencia na enunciação de algumas frases tais como: "deves sacrificar-te com entusiasmo", "deves imolar-te a ti mesmo". A moral da compaixão, que apregoa a entrega e a mortificação, detesta reconhecer que por trás de um ato de piedade e na própria entrega de si (quanto maior o sacrifício, maior a dívida gerada), o que se afirma é a existência de uma dívida que haverá de ser paga com eterna gratidão e humildade. Por isso, sentimos o pior ressentimento quando alguém se nega a aceitar nosso sacrifício. "O homem caridoso satisfaz uma necessidade de sua alma fazendo o bem. Quanto maior for essa necessidade menos se posiciona no lugar daquele que socorre e que lhe serve para satisfazer essa necessidade, e até reage duro e ofensivo em certos casos" (Nietzsche, 1978:\$334).

Limitamo-nos aqui à tentativa de responder à primeira das duas perguntas formuladas por Nietzsche, aquela que se refere especificamente à conveniência em sermos homens compassivos. Para resumir, digamos que essa conveniência pode ser analisada como uma dívida que se impõe à pessoa auxiliada e, na medida em que se trata de uma divida contraída por alguém, cuja condição é de precariedade extrema, esta retribuição esperada não haverá de ser outra que um estado de gratidão permanente. Porém, o que está em jogo é uma perigosa tranqüilidade de consciência que impossibilita a análise das conseqüências de nossas ações caridosas. Segundo Nietzsche (1978:\$134),

Em si própria a compaixão não tem de benfeitora mais do que qualquer outro instinto. Só quando a exigimos e a elogiamos - e isto acontece quando não se compreende o prejuizo que produz, quando é olhada como fonte de prazer - é que ela vem acompanhada da tranqüilidade de consciência e então nos entregamos a ela sem temer suas conseqüências.

Resta ainda delimitar em que consiste a conveniência de ser objeto de compaixão para aqueles que padecem. Se quisermos aventurar alguma resposta a essa questão, não poderemos prescindir de problematizar a distinção existente entre aquele que se compadece e aquele que é compadecido. Em outras palavras: entre aquele que se afirma, em seu gesto de entrega, como um benfeitor e aquele que, por receber assistência (ainda que esta não seja solicitada), se diz beneficiado. Esta distin- 
ção parece estar fundamentada em uma dissimetria que, na perspectiva de Nietzsche, é insuperável. Para ele, compadecer pode equivaler a depreciar. Por isso, "entre os selvagens, o homem pensa com terror em quais poderão ser as causas que o levariam a ser compadecido, pois isso seria considerado como prova de que ele carece de qualquer virtude" (Nietzsche, 1978:\$134).

Ao se manifestar piedade por alguém, está-se caracterizando essa pessoa como sujeita a alguma debilidade, como alguém que só pode superar suas limitações com a ajuda que a pessoa compassiva pode oferecer. Então, com um mesmo gesto, se estabelece uma divisão binária entre aquele que se engrandece ao realizar a ação e aquele que se diminui ao recebê-la. Como já dissemos, conceder à compaixão, à caridade ou à piedade um valor moral pode levar a crer, erradamente, que ao socorrer os outros nos engrandecemos como agentes morais e que, deste modo, podemos converter-nos em sujeitos moralmente inobjetáveis.

É justamente esta ilusão, baseada no suposto engrandecimento 'moral' de nós mesmos, que nos impede de pensar que, talvez, o gesto de compaixão não seja desejado; que talvez possa ter conseqüências negativas para o 'beneficiário'; ou que, simplesmente, possa gerar e promover estados de dependência e submissão. Algo semelhante acontece quando sufocamos o doente com cuidados que ele próprio poderia assumir, quando pelo bem de algumas pessoas 'inconvenientes' as preferimos excluir e medicalizar, quando acreditamos conhecer as necessidades e as demandas dos outros, muito antes de que elas possam ser solicitadas. Nesse jogo perverso, o infortúnio do semelhante corre o risco de converter-se em 'edificante' para os seres compassivos. Então, pode tornar-se pertinente esse irônico e implacável aforismo nietzscheano: "quando um homem é infortunado, acodem as pessoas piedosas e lamentam seu infortúnio. Quando elas saem, no fim satisfeitas e edificadas, ficaram fartas do espanto do infortunado, como se fosse seu próprio espanto, e passaram uma boa tarde" (Nietzsche, 1978:\$224).

Poder-se-ia, então, pensar que não é possível existir qualquer forma legítima de compaixão. Cabe, então, perguntar: Será que sempre depreciamos o beneficiário de nossa piedade? Não existiria um sentimento legítimo através do qual me reconheço como igual ao outro, no momento em que me compadeço de seu sofrimento? 
Aparentemente, não é possível responder de maneira afirmativa a nenhuma das questões, se tomarmos como ponto de partida o aforismo nietzscheano. Porém, haverá de ser o próprio Nietzsche quem fornecerá um suporte para refletir sobre um modo legítimo de piedade. Este pode ser um sentimento capaz de gerar vínculos positivos e moralmente legítimos somente em certos casos singulares: quando existir proximidade e identificação com a pessoa que consideramos infortunada. Quando pudermos reconhecer naquele que sofre um semelhante, alguém com o qual seja possível argumentar e discordar, formular perguntas e respostas, alguém, enfim, que possa preferir prescindir de nosso auxílio.

Para Nietzsche, minha compaixão somente pode ser definida como legítima quando um amigo admirado ou um inimigo respeitado viverem uma situação de infelicidade ou forem obrigados a padecer algum tipo de sofrimento. Isso poderá acontecer cada vez que, por causa de um infortúnio, deva enfrentar a privação desse afeto que me alegra e gratifica. Mas também pode existir um modo legítimo de piedade quando vejo "padecer um inimigo a quem considero um igual em orgulho e a quem o tormento não derrota, e em geral quando vemos padecer a um ser que não quer pedir compaixão, que é a humilhação mais vergonhosa e mais baixa" (Nietzsche, 1984:(324). Então, parece que nos defrontamos com um sentimento próximo da admiração, que, no entanto, não pode ser inteiramente separado de uma forma de piedade que é menos 'compassiva' do que 'apaixonada'.

O que diferencia o sentimento legítimo da piedade compassiva é que não existe nada que possa ser associado ao desprezo; muito pelo contrário, ele se funda em um sentimento que é próximo da admiração. Esse infortúnio não nos enaltece nem nos faz mais humanos ou mais virtuosos, simplesmente nos iguala com aquele que padece. Ainda em tais circunstâncias, é possível afirmar com Nietzsche que em si mesma "a compaixão não tem de benfeitora mais que qualquer outro instinto", que não é esse sentimento que nos faz mais virtuosos ou morais, mas, sim, os atos que de fato somos capazes de realizar. A compaixão pode tanto gerar atos virtuosos quanto representar uma debilidade moral. É assim como os estóicos a vêem: para eles não existe distinção entre piedade e inveja: "pois o homem que se compadece de outro também pode ficar aflito pela prosperidade dos outros" (Szasz, 1994:25). 
Mas, a piedade é sempre uma debilidade "para aquele que, num sentido ou em outro, quer servir de médico à humanidade. Ele tem que tomar precauções contra esse sentimento que o paralisa nos momentos decisivos, que ata sua consciência e sua mão hábil" (Nietzsche, 1978:\$134). Enfrentamo-nos com um sentimento que, em si mesmo, não é nem bom nem ruim, mas, no momento em que é exigido e exaltado como um valor moral, na medida em que fazemos desse sentimento uma regra de comportamento, capaz de definir por si próprio um parâmetro do que é moralmente desejável para um grupo humano, corremos o risco de legitimar certas estratégias de coerção que se exercem em nome e pelo bem dos considerados beneficiários.

\section{SOCIEDAdes Compassivas}

A história da humanidade apresenta muitos exemplos que podem ilustrar o exercício dessa "cruel compaixão". Talvez o primeiro deles seja a implementação, na Inglaterra, das 43 leis de Isabel, também conhecidas como Lei de Pobres. Tanto na sua implementação, através da organização e administração paroquial, que caracterizou a Inglaterra dos séculos XVII e XVIII, quanto na sua posterior revisão e reformulação, a Lei de Pobres representa o mais antigo e o mais claro exemplo de coerção compassiva.

É pela força da caridade e da compaixão que o mundo da pobreza começa a ser racionalizado, e que se pode começar a estabelecer diferenças e categorias entre os habitantes daquilo que, até este momento, formava parte do contínuo 'pobres'. Para assistir e auxiliar os pobres foi essencial, em primeiro lugar, designar lugares e funções, distribuir e fixar cada um dos necessitados em um espaço preciso. Na medida em que cada paróquia cra a responsável pela administração e gestão desse auxílio, foi indispensável que, simultaneamente, se procurasse um meio para fixar cada indivíduo dentro do espaço daquela que seria sua paróquia benfeitora. Surge assim, dentre as 43 leis, a famosa Lei de Assentamentos, que impedia que qualquer habitante do mundo da pobreza pudesse deslocar-se em direção a outros centros; excetuando-se aqueles que pudesses demonstrar que poderiam pagar, dentro do prazo de 40 dias, o aluguel de uma moradia 'digna' cujo valor não fosse inferior a dez libras. 
É evidente que em circunstâncias em que a maior parte dos trabalhadores necessitavam, em algum momento, de auxílio paroquial (seja por doença ou por falta de emprego), a Lei de Assentamentos transformava-se em instrumento de imobilização da força de trabalho. Nesse contexto em que os conceitos de 'trabalho' e de 'pobreza' eram quase sinônimos, pois era inevitável a oscilação entre o trabalho e a desocupação, essa lei parecia reivindicar para si o direito e o dever de constituirse em uma instância legítima de controle e de coerção social, que tinha por objeto vigiar essa metade 'baixa' da população que, estranhamente, era caracterizada como a que "diminui a riqueza do reino".

Um bom cxemplo desse controle é a lei conhecida com o absurdo nome de Lei da letra P. Ela obrigava todos os pobres que gozavam do privilégio da assistência, ou que pudessem, eventualmente, necessitar desse auxílio a cxibirem um distintivo: a letra $\mathrm{P}$, em tamanho claro e legivel, pintada nas costas dos agasalhos. A lei parece constituir simplesmente um ritual, pois a limitação da liberdade de deslocamento de uma paróquia a outra dificilmente poderia ser controlada pelo uso de uma letra que unificava a todos e a cada um dos 'beneficiários' do auxílio estatal.

Essa persistência, essa continuidade no tempo, de diferentcs modos de auxílio aos pobres que eram administrados e unificados por meio da ação caridosa das paróquias, encontra sua razão de ser c sua lógica na figura confusa e equívoca da 'compaixão picdosa'. Isto não implica afirmar que fosse um auxílio inútil. Sem dúvida, constitui a primeira tentativa histórica de reivindicar o direito irrenunciável e irrecusável de que as pessoas pobres pudessem satisfazer as necessidades básicas. Ainda assim, é possivel olhar para a outra face desse socorro, mostrar que a ação piedosa das paróquias possibilitou que o mundo da pobreza fosse invadido, difercnciado, classificado e fixado $\mathrm{cm}$ um cspaço preciso. Como afirma Foucault (1990:146):

com a Lei de Pobres emerge, de maneira ambígua, um importante fator na história da medicina social: a idéia de uma assistência fiscalizada, de uma intervenção médica que constitui um meio de auxiliar' aos pobres a satisfazer necessidades de saúde que, por sua pobreza, não podiam atender e que, ao mesmo tempo, permitiria manter um controle pelo qual as classes adinheiradas garantiam (...) a proteção de uma faixa privilegiada da população. 
Por muito tempo, tanto na Inglaterra quanto em outros países europeus, a assistência e o cuidado dos pobres ficou por conta da figura da 'mulher consagrada' que, como vimos, antecede à figura da enfermeira da última metade do século XIX. Entre os pobres de Deus que se beneficiam da caridade e as mulheres benfeitoras não existe nada semelhante a um intercâmbio ou a uma troca em que se reconheça a independência ou a igualdade dos agentes. Todas as relações que ali aparecem, pertencem, necessariamente, ao registro do 'dar' e do 'receber'. Como observa De Gerando (1977:87):

Há três relações principais entre os homens: dar, receber, trocar. A última supõe a igualdade ou a independência recíproca daqueles que permutam: as outras duas pressupõem a desigualdade, a necessidade de um lado, o supérfluo de outro. A caridade é, pois, o meio pelo qual uma relação entre indigência e abundância se mantém basicamente justa.

A caridade é, pois, o modo de legitimar as desigualdades, de naturalizar a lógica das compensações entre o supérfluo e a carência do necessário. Por meio dessa dissimetria anula-se toda reciprocidade, porém, se alimenta, ao mesmo tempo, uma necessidade de reconhecimento. Os pobres de Deus "estão sempre em dívida do bem que lhes é feito e não tomam consciência da dependência em que são mantidos" (Collière, 1989:71).

Encontra-se aí um risco inerente à figura da mulher benfeitora: na medida em que centra todos os cuidados e toda a atenção na pobreza, pode correr o perigo de reforçar esse sofrimento e essa pobreza, convertendo-os em num mal que é necessário para poder exercer o bem.

"Hospícios e Hospitais são estações obrigatórias no trajeto de assistência generalizada, verdadeiras bases de apoio de uma política de controle difuso das famílias e observatório privilegiado das espécies e das formas de indigência" (De Gerando, 1977:89). A mulher consagrada contribui, assim, para estabelecer as demarcações e classificaçōes que desarticulam o antigo 'contínuo pobres', em diferentes tipos de pobreza: a digna e a indigna, a laboriosa e a ociosa, a doente e a saudável, enfim, a pobreza considerada normal e o estado patológico que devia ser assistido e normalizado. Essas demarcações adotaram um estatuto jurídico com a Nova Lei de Pobres. Somente em 1843, quando 
essa lei foi promulgada, é que a Lei de Assentamentos foi derrogada. Apesar de vigorar em um contexto absolutamente contrário às necessidades que as novas demandas industriais impunham, a Lei de Assentamentos pôde persistir por mais de dois séculos. Ela só foi revogada no momento em que se excluíam os pobres adultos e saudáveis, capazes de trabalhar, de qualquer outro auxílio que não fossem as work-bouses.

Cabe perguntar o que era essa Lei de Pobres que marcou o início da chamada Época da Bondade. Ela definia-se como uma lei capaz de garantir "trabalho para os que querem trabalhar, castigo para os que não querem e pão para os que não podem" (Himmelfarb, 1988:40). Entre os beneficiários incluíam-se, inicialmente, tanto os pobres dependentes quanto os independentes, os pobres dignos quanto os indignos, os que deviam ser castigados e os que deviam ser auxiliados. A diferença entre eles só se estabelecia através do tipo de auxílio a que tinham direito, ainda que essas distinções nunca ficassem completamente claras.

Em princípio, todos os pobres habitantes da Inglaterra, em algum momento, eram beneficiários da caridade, ainda que existissem diferentes tipos de auxílio para os diferentes tipos de pobres: "esmolas e asilos para os idosos e doentes, aprendizado de ofícios e escolas de caridade para as crianças, castigo e clausura para os 'andarilhos teimosos', e trabalho para os sadios" (Himmelfarb, 1988:33). Surgiram então os asilos de pobres onde encontravam socorro tanto velhos e doentes, inválidos e soldados descrtores, crianças abandonadas e pessoas sem lar. Por sua vez, os regulamentos quase religiosos das work-houses, onde mulheres e homens eram empregados para trabalhar, trocavam moradia e comida pela imobilidade a que os sujeitava um salário pago somente depois de um ano de trabalho. Multiplicaram-se por toda Inglaterra as escolas de caridade, onde, conforme explica Thompson (1987), dificilmente as crianças puderam atingir algo mais do que rudimentos de escrita e de leitura centrada na Bíblia.

Um de seus mais acérrimos críticos, Mandeville (apud Himmelfarb, 1988:39) afirmava que, sendo tão pouca a influência moral que a educação tinha entre os ricos, seria inútil e desatinado pretender estendê-la aos pobres: 
Para fazer a sociedade feliz e para que o povo ficasse sossegado nas piores circunstâncias, requer-se a existência de grande quantidade de ignorantes e pobres. $O$ conhecimento acrescenta e multiplica nossos desejos, e quanto menos coisas deseje o homem, mais facilmente pode satisfazer suas necessidades.

Incomuns, as críticas de Mandeville não eram aceitas na Época da Bondade. Esse cinismo conservador irritava os homens sensíveis da Inglaterra que, no entanto, conseguiram responder às críticas, em um tom que se iguala em brutalidade e cinismo. Os defensores das escolas de caridade escolheram dar uma resposta sincera:

Os pobres, longe de serem corrompidos pela educação, aprenderão a tolerar sua pobreza com maior fortaleza, serão dissuadidos a levar uma vida de dissipação e delito e aprenderão as virtudes e as habilidades, que os tornarão melhores operários e melhores pessoas. (Himmelfarb, 1988: 40)

De fato, todos os projetos filantrópicos desse período se caracterizam pela ambigüidade. Se, por um lado, se apresentam como uma forma de assistência caridosa dirigida aos necessitados, por outro, se apresentam como dispositivos de controle e coerção social. Dois exemplos imaginados por William Petty podem ser significativos: o projeto de criar um hospital para apestados semelhante a um leprosário, isto é, uma instituição de isolamento e exclusão; e o projeto de criar uma maternidade para solteiras pobres. O Estado, então, tomaria a seu cargo a assistência e a proteção das mães, mas imporia como forma de pagamento que os filhos ficassem sob sua tutela durante 25 anos, contribuindo para aumentar a sua riqueza (Rosen, 1985). Ainda que tais projetos nunca tenham sido aprovados, é significativo que fossem imaginadas instituições filantrópicas que unificavam, de um modo tão evidente e pacífico, caridade e controle social.

A necessidade e a sujeição dos pobres constituem uma garantia de obediência, porém, representam "também a impossibilidade, a incapacidade de se situar em uma relação de paridade e a possibilidade de evitar um enfrentamento com diversas formas de relacionamento social que exijam julgamento e discernimento" (Collière, 1989:68). Assim, a mulher consagrada pode associar o imperativo de respeito por aqueles 
que sabem (os médicos) e a exigência de submissão e de aceitação por parte dos doentes. A benfeitora encontra compensação afetiva e social na submissão e na gratidão daqueles de quem cuida.

O pobre desamparado é, antes de tudo, a garantia de uma eterna obediência. Assim, na dedicação e na entrega de sua vida aos pobres, a mulher consagrada encontra a razão de sua existência.

A compensação de tanta abnegação pode encontrar-se numa valorização espiritual e social importante que lhe permite, sem dúvida, encontrar a força para assegurar a sua tarefa (...). É assim que pode realizar a sua função materna, sublimada numa maternidade espiritual dos doentes a tratar, dos pecadores por quem é preciso rezar. (Collière, 1989:70)

\section{COMPaIX̃̃o ApaIXonada}

Algo unifica todos os benfeitores: 'os bons sentimentos', a compaixão pelos doentes. Ou, como diria Rousseau, "uma repugnância inata em ver o sofrimento de um semelhante". É assim que os filantropos ingleses se aproximam dos revolucionários franceses, no momento em que se identificam com aqueles princípios que Rousseau isolou e caracterizou melhor do que qualquer outro pensador. A partir de Rousseau, o interesse e a preocupação pelos outros transforma-se em paixão. Segundo a tese de Himmelfarb, esta prioridade concedida à compaixão está longe de ser exclusiva de Rousseau; para ela, os filósofos morais ingleses, os filantropos, também sustentaram seus projetos e idéias

na benevolência, no humanismo, na simpatia, e nos afetos sociais: eles até usaram a palavra "compaixão", no mesmo sentido. Como Rousseau, eles situaram esse sentimento no coração da natureza humana, convertendo-o no atributo característico mais importante da humanidade, e encontrando evidências em todas as esferas da vida. (Himmelfarb, 1988:48)

É verdade que os filósofos ingleses souberam sublinhar o caráter desinteressado e solidário da compaixão. Porém, muitos dos projetos defendidos pareciam silenciar seu caráter solidário, reforçando, em tro- 
ca, a face mais coerciva. Como já apontado, este não é um dado secundário: no preciso momento em que a compaixão e a piedade se convertem em parâmetros de moralidade, em que faço extensivo um sentimento que só pode existir na intimidade (entre sujeitos que se reconhecem semelhantes), para o extenso mundo dos pobres ou dos sofredores, a piedade perde seu caráter de sentimento legítimo e se torna uma eficaz estratégia de poder.

Arendt (1990:71) soube resumir em poucas palavras os perigos próprios da sobrevalorização da compaixão e da piedade: "A piedade, tomada como fonte de virtude, tem demonstrado possuir uma capacidade para a crueldade, maior do que a própria crueldade. Par pitié, par amour pour l'bumanité, soyez inbumains". Foi isto o que legitimou, para a autora, o exercício do terror nos anos que sucederam à Revolução Francesa, crueldade que ficou para sempre associada ao nome de Robespierre. Para ele, a ação política deveria sustentar-se "naquele impulso imperioso que nos atrai para les bommes faibles", nessa capacidade de "sofrer com a imensa classe dos pobres" (Arendt, 1990:60).

Certamente, essa valorização da piedade como fonte de toda virtude é uma herança do pensamento de Rousseau; mais especificamente, provém das teses sobre a 'comiseração' que aparecem em $O$ Discurso sobre a Origem da Desigualdade entre os Homens. Para ele, todos os valores humanos e todas as virtudes sociais se derivam de uma única virtude que é a compaixão.

Com efeito, que são a generosidade, a clemência, a humanidade, mais do que a piedade aplicada aos fracos, aos culpados ou à espécie humana em geral? (...) Ainda quando fosse verdade que a comiseração não é mais do que um sentimento que nos posiciona no lugar daquele que sofre, sentimento escuro e vivo no homem selvagem, desenvolvido, porém mais fraco, no homem civilizado. (Rousseau,1984:93)

Perante a razão que isola, que estimula o amor próprio e o egoísmo, Rousseau venera a força niveladora de uma paixão primitiva e natural, a mais selvagem de todas as paixões, pois é o "sentimento primeiro de toda a humanidade". A piedade auxilia os homens racionais a moderar o amor próprio e, na medida que se trata de um sentimento natural, desnuda a valentia dos mais simples: "a ralé, as mulheres da feira, são as 
que separam os combatentes, as que impedem os homens decentes seu mútuo extermínio" (Rousseau,1984:94).

Por oposição a essa ousadia da piedade, Rousseau (1984:96) decide situar a racionalidade sob a figura do filósofo que prefere tapar os ouvidos ao clamor do sofrimento alheio e "argumentar um pouco para impedir a natureza que nele se subleva que o identifique com o assassino". Estes e outros exemplos falam da grandiosidade dessa virtude natural que é a piedade, ela nos leva "sem reflexão, ao socorro dos outros" (1984:94), ao auxílio imediato e não refletido daquele que vemos sofrer. No momento em que esse ser que sofre, já não é um sujeito individual e próximo, quando os sofredores são o conjunto de um povo chamado também de 'pobres', 'miseráveis', 'homens fracos', 'desgraçados', esse socorro imediato e irrefletido quase inevitavelmente se converterá em um modo de legitimar a violência.

Em sua exaltação da piedade como virtude, Rousseau se opõe ao pensamento grego. No Discurso podemos ler que: "ainda que possa corresponder a Sócrates e aos gênios de sua têmpera a aquisição da virtude pela razão, faz muito tempo que o gênero humano não existiria se sua conservação tivesse dependido exclusivamente dos razoamentos dos indivíduos que o compõem" (1984:95). Contra essa afirmação,

A história nos diz que de modo algum é uma coisa natural que o espetáculo da miséria mova os homens à piedade; mesmo durante os longos séculos em que a religião cristã de misericórdia impôs padrões morais à civilização ocidental, a compaixão se manifestava fora do domínio político. (Arendt, 1990:56)

Voltcmos agora aos gregos e lembremos que, segundo Aristóteles (1980:1095),

Nem as virtudes nem os vícios são paixões, pois não somos chamados de bons ou de maus em razão de nossas paixões. Aquele que vive conforme manda a paixão não ouvirá argumentos que venham a dissuadi-lo, nem os compreenderá... A paixão parece conduzir, não ao argumento, mas à força.

Como Arendt soube mostrar, a esfera de discussão e diálogo, o jogo de perguntar e responder, faz parte desse âmbito da existência que os 
gregos isolaram como o âmbito do 'propriamente humano'. Ele define-se por um modo de existir entre iguais, que exige o uso das artes da dialética e da retórica. Por isso, Aristóteles acrescenta à definição de homem como zoon politikon, uma segunda especificação pela qual o homem pode ser pensado como zoon logon ekhon, isto é, ser vivo capaz de discurso.

A pólis era esse espaço onde tudo devia ser enunciado, onde a violência podia ser excluída para fora de seus muros. "Para o modo de pensar grego, obrigar as pessoas pela força, mandar em lugar de persuadir, cram formas pré-políticas para tratar com pessoas cuja existência estava nas margens da pólis" (Arendt, 1993:33). Certamente era isso o que permitia aos gregos conviver com formas despóticas de organização, como a escravidão ou o patriarcado. Coexistiam, assim, espaços onde regia a violência muda junto com espaços de diálogo entre iguais, que eram considerados como a esfera do propriamente humano. Escravos, bárbaros e mulheres eram aneu logou (sem logos). Claro que isto não significa que eles estivessem "desprovidos da faculdade do discurso, mas sim de uma forma de vida na qual o discurso e só ele tinha sentido, e onde a preocupação primeira entre os cidadãos era falar entre eles" (1993:44).

Ainda segundo Arendt (1993:41):

os filósofos gregos, seja qual for sua posição a respeito da pólis, não duvidaram de que a liberdade se localiza exclusivamente na esfera política, que a necessidade é de maneira fundamental um fenômeno pré-político (...) e que a força e a violência se justificam nessa esfera porque são os únicos meios para dominar a necessidade e chegar a ser livres.

Aí está a maior dificuldade em pensar a compaixão dentro da esfera da política. Ela permanece alheia a esse âmbito que é próprio do diálogo entre iguais. Pretende superar uma necessidade que é urgente e imediata. Enfrenta-se com o sofrimento e com a miséria, não com o sofrimento singular de determinado indivíduo, com o qual posso me identificar, mas sim com o sofrimento de um grupo, aquele dos chamados 'miseráveis'.

Superar esse sofrimento através da compaixão significa excluir o diálogo e a argumentação da cena política e substituí-los pelo imediatismo da força. Implica também sair do âmbito da liberdade para 
ingressar no registro da violência, pois essa esfera da liberdade estava simbolizada pela palavra, pelo diálogo entre iguais, um diálogo que nem sempre significava harmônica convivência, mas, sim, exclusão de formas pré-políticas e mudas de violência.

Para o pensamento de Rousseau, e daqueles que levaram seus ensinamentos para a cena política, era preciso liberar a mais primitiva e natural das paixões humanas das correntes que a razão impõe, então poderia lograr-se que essa "repugnância inata em olhar o sofrimento de um semelhante" possa substituir à indiferença reinante. Como já assinalamos, é pela razão que, para Rousseau, o homem se transforma em 'egoísta' e perde a capacidade para "se identificar com o infortunado" (Arendt, 1990:63).

Da perspectiva de Arendt, Rousseau só pode concluir que a capacidade de refletir nos isola e nos faz despreocupados em relação aos outros, porque ele desconhece que o pensamento político é essencialmente representativo. Rousseau não pode aceitar que o pensamento seja um diálogo sempre mediatizado por "numerosos pontos de vista que tenho presentes em meu espírito, no momento em que avalio uma questão; e, quanto melhor posso imaginar de que modo sentiria se estivesse no lugar desses outros, tanto mais forte será minha capacidade de pensamento representativo" (Arendt, 1992:300). O que caracteriza o pensamento é o caráter discursivo, a possibilidade de deslocar-se de um ponto de vista até outro, passando por pontos de vista diferentes e antagônicos tentando atingir uma generalidade imparcial.

O pensamento, longe de isolar-nos na interioridade do eu, nos obriga a fazer um esforço por integrar posições diversas, por imaginar como atuaríamos no lugar dos outros. Ele estabelece um diálogo com aqueles outros que estão presentes em nosso espírito, quando avaliamos uma questão, embora isso não implique que devamos recorrer ao sentimento de 'empatia'. Existe uma única condição para esse processo de formação de uma opinião refletida que são o desinteresse, a libertação de nossos interesses pessoais, ou a capacidade de tornar nossa posição a mais universal possível.

Em oposição ao que ocorre com o pensamento político, a compaixão nunca pode ir para além do individual, ela implica essa capacidade 
de sentir, na própria pele e no próprio corpo, o sofrimento alheio: "como se fosse alguma coisa çontagiosa" (Arendt, 1990:67). A compaixão caracteriza-se, como foi explicitado a partir de Rousseau, por

uma aversão a qualquer espécie de diálogo conciliatório e argumentativo, onde alguém fala com outro sobre alguma coisa que é de interesse de ambos. Esse interesse no mundo, loquaz e argumentativo, é inteiramente alheio à compaixão, que se dirige unicamente e com veemente intensidade ao próprio homem que sofre. (Arendt, 1990:70)

A compaixão é necessariamente um co-sofrimento que não pode ir além do padecimento de um semelhante. Ela apaga as diferenças, elimina o espaço material que separa os homens, aproxima as pessoas, não pela palavra, mas sim pelos gestos ou pelos silêncios. "Sua força reside na força da própria paixão, que, à diferença da razão, só pode olhar para o particular, pois não possui noção do geral nem capacidade de generalização" (Arendt, 1990:68). Para que os gestos e os silêncios possam tornar-se significativos é preciso que esse co-sofrimento associe entre si os sujeitos que se reconhecem como semelhantes. Só então, como diz Nietzsche, estaremos frente a uma compaixão legítima, em que não existem relações dissimétricas, em que os vínculos não encontram seu fundamento no desprezo, mas sim no reconhecimento do outro como um igual em orgulho e dignidade.

É necessário problematizar, também, esse preciso momento no qual a compaixão se faz extensiva às relações sociais, esse momento em que um sentimento individual, às vezes legítimo, outras ilegítimo, ingressa no âmbito do público.

Arendt (1990:70) estabelece uma distinção entre os conceitos de 'compaixão' e 'piedade' que pode auxiliar na compreensão desta questão. Para ela, só é possível falar de compaixão quando existe esse vínculo imediato a que já fizemos referência. Então fica "eliminado o espaço material entre os homens, onde se localizam os eventos políticos e todo o universo das relações humanas". Isso implica afirmar que a compaixão é, "do ponto de vista político, irrelevante e sem conseqüências". Efetivamente, não será a partir da compaixão que podem ser iniciadas modificações reais nas 'condições materiais', capazes de aliviar o sofri- 
mento das pessoas. E, a partir do momento em que se pretende fazê-lo, é inevitável que sejam "eliminados os extenuantes processos de persuasão, negociação e acordo, que são próprios da lei e da política, e que se empreste a VOZ ao próprio sofrimento, que clama por ação direta e rápida, isto é, ação com os meios da violência" (1990:790).

Chegamos, assim, por uma via argumentativa absolutamente diferente da de Nietzsche, aos limites e riscos inerentes a uma exaltação moral da compaixão. Seja porque ao realizar uma ação compassiva se pretenda um reconhecimento como agente moral, seja porque se pretenda fundar nela políticas de assistência mais 'humanas'.

Se a compaixão só pode referir-se ao singular, é a piedade que assume a função de generalizar esse sentimento às grandes massas de 'sofredores'. A piedade diferencia-se da compaixão na medida em que não se trata de uma paixão vivida individualmente, mas de um sentimento que, igual a qualquer outro, encontra o prazer na própria existência. Mas a piedade pode ser também a perversão da compaixão no momento que ao desmontar essa figura próxima do co-sofrimento, ao ampliar o horizonte para o mundo dos 'fracos', inevitavelmente corre o risco de glorificar essa mesma debilidade que a faz existir.

A piedade, ao contrário da solidariedade, não considera da mesma maneira a fortuna e o infortúnio, o forte e o fraco; sem a presença do infortúnio, a piedade não pode existir, e, portanto, tem exatamente o mesmo interesse na existência dos infelizes, que a sede do poder na existência dos fracos. (Arendt, 1990:71)

A própria existência da miséria alimenta a piedade, uma vez que é pela grande massa dos que sofrem que este sentimento encontra seus alicerces e sua razão de ser. Na verdade, as relações estabelecidas a partir da piedade serão necessariamente dissimétricas, então já não existe nenhuma possibilidade de gerar vínculos legítimos entre agentes morais.

$\mathrm{Na}$ medida em que a piedade estende ao âmbito do público um sentimento que pertence inicialmente ao privado, se torna indispensável que ela saia da 'obscuridade do coração', onde encontrava seu local, e se exponha ao mundo público. A compaixão que, como vimos, pretendia ser refratária a todos os argumentos e palavras, precisa ser enunciada quando entra no mundo das relações sociais sob a forma de pie- 
dade. Assim, a declaração de que cada ato que se realiza está motivado em um sentimento piedoso faz surgir a suspeita da falsidade, da mentira e da hipocrisia. Sabemos que, quase inevitavelmente, a enunciação pública da própria bondade é a forma mais usual de ocultar outras 'motivações sub-reptícias'. Sabemos também que são muitos os sentimentos, entre eles a compaixão, que, na medida em que permanecem ocultos podem ser corretos, mas que deixam de sê-lo no momento preciso em que decidimos comunicá-los publicamente, quando então começam a ter o gosto desagradável da 'hipocrisia'.

Declarar nossa bondade, torná-la pública, parece legitimar o direito de exigir que os outros reconheçam, também, suas motivações ocultas. Porém, todos ficam, assim, sob suspeita: tanto aquele que declara suas motivações bondosas, altruístas e piedosas como aquele que prefere calar e reservar suas paixões, sejam elas compassivas ou não, ao silêncio do privado. Como afirma Arendt (1990:79),

A exigência de que todos anunciem em público suas motivações íntimas transforma a todos os atores em hipócritas; no instante em que se inicia a exibição dos motivos, a hipocrisia começa a envenenar as relações humanas. Ademais, o esforço por arrancar o que está obscuro e escondido para a luz do dia só pode resultar numa livre e ruidosa manifestação daqueles atos cuja própria natureza os leva a procurar a proteção da escuridão.

Cabe agora repetir a pergunta formulada anteriormente: se a compaixão só pode ser legítima no vínculo imediato, no reconhecimento que existe entre iguais, e se a piedade pode ser considerada sua perversão (na medida em que pretende estender esse co-sofrimento às grandes massas dos sofredores), então não existiria nenhum princípio capaz de guiar ações para diminuir ou anular o sofrimento alheio? A alternativa à piedade, como perversão da compaixão, é para Arendt a 'solidariedade'. Já não se trata de um sentimento que leve em si próprio seu prazer; nem de uma atração pelos homens fracos que reforce a polaridade entre posições dissimétricas. A solidariedade encontra seu fundamento na simetria dos interesses, em uma desapaixonada comunidade de interesses com os infortunados, na medida em que todos compartilham uma única preocupação por universalizar a dignidade humana. Assim, ainda que uma ação eficaz possa ser motivada pelo sofrimento, nunca é por ele 
guiada, pois ela deve compreender "tanto os fortes e os ricos, quanto os fracos e os pobres. Comparada com o sentimento de piedade, ela pode parecer fria e abstrata, pois permanece mais comprometida com idéias - grandeza, ou honra, ou dignidade - do que com qualquer amor pelos homens" (Arendt, 1990:70).

A solidariedade supera o vínculo imediato do co-sofrimento porque ela não é silenciosa nem gestual. Precisa da mediação das palavras e do diálogo, para poder generalizar-se. É próprio da compaixão e da piedade igualar, apagar as diferenças entre os que sofrem, unificá-los sob o nome de infortunados. Como afirma Nietzsche (1981:\$134) "o próprio do sentimento de compaixão é despojar a dor alheia do que ela tem de pessoal", de individual e irrepetível. A solidariedade procura, em troca, tomar como ponto de partida as diferenças, uma pluralidade humana considerada irredutível. Perante a impossibilidade de falar de uma natureza que nos unifique, ou que unifique os que sofrem, Arendt (1993:22) pensa a condição humana em função da categoria de "pluralidade". "A pluralidade é a condição da ação humana, pois todos somos o mesmo, isto é, humanos, e, portanto, ninguém é igual a qualquer outro que tenha vivido, viva ou viverá jamais". Porque existe diferença, mais do que identidade essencial, a ação e o diálogo não são luxos desnecessários, mas sim elementos constitutivos desse 'nós' que somos. A condição humana pode realizar-se a partir do momento em que participamos do âmbito da vida ativa, onde os vínculos devem ser necessariamente, mediatizados pela palavra (único modo de garantir a exclusão da violência).

Por fim, resta dizer que, atribuir prioridade à solidariedade sobre a piedade, à monotonia do diálogo entre iguais sobre a aparente luz do sentimento, permite excluir qualquer forma de glorificação da miséria e, conseqüentemente, qualquer interesse sentimental em sua existência. "Por tratar-se de um sentimento, a piedade pode encontrar em si própria seu prazer, isso leva, quase que automaticamente, a glorificar sua causa: o sofrimento alheio" (Arendt, 1990:71). Assim, e pela patética lógica da piedade, a miséria e o sofrimento deixam de ser obstáculos que devem ser superados tecnicamente para se converterem em uma realidade triste que devemos tolerar. Isto porque, em virtude de sua existência, o compassivo pode se reconhecer como um sujeito benfeitor, se regozijar no prazer que decorre de sua bondade filantrópica e 
caridosa. Pela lógica perversa da piedade, a miséria legitima a mesma dissimetria de poder que a gerou.

\section{Assistência e PIedade}

Acreditamos que a glorificação do sofrimento alheio, que faz da dor e da miséria elementos necessários para que o benfeitor seja reconhecido como um agente moral, se faz evidente na assistência médica sempre que ela se apresenta sob a forma de um 'socorro' ou de um 'auxílio compassivo' a quem sofre. Nesse sentido, parece-nos obrigatória uma remissão ao texto de Thomas Szasz (1994), Cruel Compaixão, em que o autor tematiza as ambivalências e os perigos que inevitavelmente parecem associar-se com diversas formas de assistência compulsiva dirigidas a uma figura paradigmática: o "adulto fisicamente capaz mas improdutivo". São desmontados ali, pouco a pouco, esses mecanismos obscuros, históricos e cotidianos, através dos quais a piedade se revela como uma perigosa tecnologia de poder que, porém, gosta de se apresentar com a máscara de um desapaixonado e inevitável 'humanismo'.

Para exercer essa piedade com a ferocidade e o rigor que lhe são próprios, será necessário que possa fazer do doente (Szasz se refere à doença mental) um sujeito desprovido dos direitos elementares. Iniciase, então, um processo pelo qual as consideradas 'patologias' serão caracterizadas e classificadas de modo ambíguo como um padecimento que infantiliza os homens. Assim, os doentes mentais, considerados como crianças, passam a ser tratados como alheios a qualquer obrigação e, conseqüentemente, a qualquer direito. Pode resultar assim politicamente legítimo pensar esses doentes-crianças como não responsáveis; porém, essa identificação não é gratuita: somente na responsabilidade é que a liberdade acha sua condição e sua razão de ser. É, então, evidente afirmar que ausência de responsabilidade haverá de ser idêntico a afirmar ausência de liberdade.

Podemos agora retomar a pergunta que formulamos no início: é possível imaginar e propiciar a criação de um saber médico que, renunciando a ser um instrumento de controle, possa afirmar-se em um espaço solidário de vínculos legítimos entre iguais? 
Se tomarmos como ponto de partida a crítica dos conceitos de compaixão e piedade aqui esboçada, talvez possamos aventurar uma primeira resposta, necessariamente parcial e fragmentária. Da leitura de Nietzsche e Arendt pode-se concluir, em primeiro lugar, que, no âmbito da assistência ou do saber médico, não deveria existir nenhum espaço reservado para a compaixão ou a piedade, pois, a partir do momento em que a 'razão terapêtica' se apresenta a si própria como compassiva, corremos o risco de reforçar a dependência do paciente e, conseqüentemente, menosprezar sua capacidade de decisão, de ação, de eleição e de diálogo refletido.

A razão terapêutica deve enfrentar-se quase inevitavelmente com sujeitos que se consideram prisioneiros da debilidade que impõe o sofrimento. Torna-se indispensável que o saber médico apele a estratégias capazes de impedir que essa sujeição inicial (muitas vezes inevitável) se possa converter em passiva aceitação, isto é, na naturalização de relações dissimétricas de poder. Contrariando este pressuposto, a lógica da compaixão demonstrou notória eficácia como instrumento capaz de garantir e reforçar a dissimetria inicial.

Como já assinalado, a compaixão é silenciosa, refratária às palavras e a qualquer forma de diálogo. A comiseração, fundada neste reconhecimento imediato, pode falar por meio de gestos, de olhares ou de carícias, mas nunca apelará para argumentos pelos quais uma intervenção médica sobre nosso corpo possa se tornar inteligível e conseqüentemente passível de ser aceita ou rejeitada. Uma vez que a compaixão parte do pressuposto de que é, pela sua mediação, que as pessoas se aproximam e que se podem apagar as distâncias, as palavras tornam-se supérfluas. Porém, é fundamental reconhecer que, na condição de sofredores, quando nos enfrentamos com o limite da dor, sempre nos assumimos como 'diferentes', nos reconhecemos participando de uma pluralidade humana que rejeita as homogeneizações. Através da experiência individual do sofrimento, nos reconhecemos como únicos e insubstituíveis, como diferentes; mas, ao mesmo tempo, essa experiência nos torna partícipes da condição humana, como condição universal.

Todos compartilhamos dessa capacidade propriamente humana de sofrer dor e de temer a morte, mas sabemos que somente a capacidade humana de falar, de dizer, pode ser equiparada a essa experiência indi- 
vidual do sofrimento, em universalidade e singularidade. É através do diálogo e da argumentação que podemos enunciar nossas experiências mais íntimas, adquirindo, assim, inteligibilidade tanto para mim quanto para os outros. É pela mediação dessa capacidade dialógica, que define e possibilita a existência da pluralidade humana, que nos podemos deter a pensar sobre nossa vida e nosso corpo. Por isso, se admitirmos que o que caracteriza nosso pensamento é o caráter discursivo, então só será pela mediação da palavra trocada com outros que poderemos confrontar nossas crenças com pontos de vista diferentes e ainda antagônicos aos nossos. Só então haverá de ser possível a enunciação de nossas dúvidas e de nossos medos, tentando atingir certo grau de inteligibilidade e certa capacidade de decisão sobre nossa situação.

Todos estamos sujeitos à dor, à doença e todos tememos a morte, porém, essa experiência, longe de nos unificar, banindo as diferenças, nos confronta com o fato incontestável de uma pluralidade de experiências e de pareceres sobre os quais temos o direito e a obrigação de refletir. Segundo Arendt (1980:25):

Por mais interessantes que as coisas do mundo pareçam, por mais profundamente que possam nos emocionar e estimular, elas não se tornam humanas para nós, até o momento em que possamos discuti-las com nossos semelhantes. Tudo o que não pode ser objeto de diálogo pode muito bem ser sublime, horrível ou misterioso, mas não é verdadeiramente humano. Humanizamos o que passa no mundo e em nós, quando falamos, e com esse falar aprendemos a ser humanos.

No instante em que, pela força da compaixão, a razão terapêutica silencia todas as palavras, o co-sofrimento mudo substitui os argumentos e a proximidade do sentimento anula as distâncias e as mediações que o diálogo pressupõe, corremos o risco de reforçar formas coercivas de assistência. Então, é a própria humanidade que fica entre parênteses. O co-sofrimento excluirá a razão terapêutica do âmbito do propriamente humano, inserindo seus atores em um mundo que bem poderá vir a ser de deuses ou de escravos, mas que, dificilmente, haverá de ser um mundo de homens. Um mundo transido pelo dizer e pelo fazer humanos; os únicos capazes de gerar vínculos simétricos que excluam a coerção e a violência. 
- Lembremos que Platão, em As Leis, pela primeira vez, propõe-se a distinguir uma medicina inteiramente empírica, que prescinde da argumentação, da persuasão e do vínculo dialógico, de uma medicina preocupada com a instauração de um diálogo simétrico entre sujeitos que se reconhecem como iguais, em que não se pode prescindir da força, da argumentação e da persuasão. A medicina, para ser considerada sábia e não puramente empírica, precisa

trocar opiniões com o próprio doente e seus amigos e próximos, e, ao mesmo tempo que [o médico] aprende junto aos doentes, instrui, na medida do possível, o próprio paciente, sem lhe prescrever nada (...); e, assim, auxiliado pela persuasão, acalma e prepara continuamente seu paciente, até conseguir restituir, pouco a pouco, sua saúde. (Platão, 1980:720)

Só então é possível falar de uma medicina que homens livres exercem em benefício de homens livres, tendo superado deste modo os limites que impostos por uma medicina de escravos, dirigida a escravos. Essa última caracteriza-se, em troca, pelo fato de ser expeditiva e prescritiva, sempre segura, sem deixar lugar para a reflexão ou as dúvidas:

nenhum destes médicos dá nem aceita explicação alguma sobre os casos individuais dos diferentes servos, mas prescreve aquilo que sua experiência sugere, como se estivesse perfeitamente informado, adotando a postura de um tirano, e, após isso, apressase em atender outro doente. (Platão, 1980:720)

Entre ambas as medicinas existe uma diferença essencial, a exclusão da palavra trocada e, conseqüentemente, a eliminação do direito de fazer de nossa própria dor algo inteligível, algo em relação ao qual possamos ter uma opinião e um julgamento. Karl Jaspers (1988:61), citando esse texto de Platão, lembra uma velha história segundo a qual, estando doente, Aristóteles interrogou o seu médico, dizendo: "mostra as razões de teu fazer, e, se as achar razoáveis, então as haverei de seguir".

A exclusão do âmbito do saber médico de "razoáveis perguntas e de razoáveis respostas" (Jaspers, 1988:62) faz dele algo inapelável e, conseqüentemente, o aproxima das legislações tirânicas. Assim, na medida em que pretendermos fundamentar a assistência médica através da 
compaixão que pela sua lógica interna exclui a mediação do diálogo, corremos o perigo de aproximá-la de formas de ação tirânicas.

Talvez seja por isso que essas estratégias mudas e coercivas que se exercem sobre os corpos (pensemos na medicalização e hospitalização dos 'loucos' ou dependentes) insistem em apresentar-se como formas compassivas e piedosas de socorro e assistência. Se, tal como propusemos no início, desconsiderarmos a existência de uma estratégia maquiavélica, que se apresenta como compassiva para poder exercer mais livremente seu poder; constataremos que existe uma solidariedade não enunciada entre a lógica própria da compaixão piedosa e essa racionalidade utilitarista, estruturada segundo parâmetros de urgência social e de bem-estar geral, que está por trás das mais diversas instituições de controle social.

Tanto a razão utilitarista quanto a compaixão piedosa partem de uma certeza. Sempre agem invocando o nome e o bem daqueles que dizem assistir. Ambas conhecem esse bem de modo claro e distinto, ainda antes que seja solicitado. Ambas prescindem de argumentos, excluem as palavras e silenciam qualquer diálogo fundado em perguntas e respostas razoáveis. A razão utilitarista, à medida que substitui essas razões pelas normas inapeláveis que prescreve. A compaixão piedosa, pela força do sentimento compartilhado, que aproxima os sofredores, sem necessitar da mediação de argumentos. Como afirma Nietzsche (1984:\$338), o compassivo nada entende de razões, "o coração o manda socorrer e ele acredita fazê-lo melhor, quanto mais imediato for o socorro".

Por isso acreditamos que é possível pensar que não é por ironia, mas sim por estrita complementaridade, que os filantropos podiam insistir em apresentar suas instituições disciplinares sob a retórica da compaixão. Pretendiam moldar os corpos, multiplicar sua docilidade e sua força, mas ao fazê-lo procura-se integrar aos 'desviados' sob um olhar médico capaz de restituí-los ao mundo da saúde e da normalidade. Uma normalidade na qual, pela arte do socorro e da caridade, todos os homens possam confraternizar, libertando-se assim dessa 'repugnância inata' que gera o sofrimento de um semelhante.

Talvez seja essa complementaridade que explique as razões do contrato tácito que possibilitou o nascimento da clínica. Contrato pelo qual 
se articulam de um modo indissolúvel "o hospital onde se cura os pobres e a clínica, onde se forma os médicos" (Foucault, 1987:125). Já no início, a hospitalização caridosa dos pobres e a emergência da clínica complementam-se uma à outra. Enquanto o pobre se beneficia de uma assistência gratuita, o saber médico tem sua retribuição na possibilidade de aprender, observar e lecionar, através de um olhar atento que se dirige ao espetáculo representado pelos corpos doentes. Haverá de ser esse saber que, mais tarde ou mais cedo, poderá beneficiar os benfeitores compassivos, pois será aplicado na cura de suas futuras doenças. "O que é benevolência a respeito do pobre transforma-se em conhecimento aplicável ao rico" (Foucault, 1987:127).

Com o nascimento da clínica, a distinção platônica antes aludida, começa a deixar de ter significação. A partir de então, tudo ficará sob o registro de um olhar médico que desloca, pouco a pouco, a persuasão, a argumentação e o diálogo, agora também do mundo dos cidadãos livres. Esse olhar, juntamente com o nascimento do hospital medicalizado (seu complemento indissociável), contribuíram para que possam vincular-se e reforçar-se três modos diferenciados e privilegiados de medicalização que ainda subsistem. Como afirma Foucault (1990:153):

A assistência médica do pobre, o controle da saúde da força de trabalho e a indagação geral da saúde pública protegem as classes mais ricas dos perigos (sanitários) gerais, e também permitem a construção de três sistemas médicos superpostos e coexistentes: uma medicina assistencial voltada aos mais pobres, uma medicina administrativa, encarregada de problemas gerais como vacinas, epidemias, etc. e uma medicina privada, que visava beneficiar a quem tinha os recursos para pagar.

Se nos perguntarmos agora pela medicina assistencial dedicada aos pobres e retomarmos as críticas dirigidas ao conceito de compaixão aqui esboçadas, deveremos perguntar também pelo conceito de piedade que, segundo Arendt, constitui seu equivalente genérico. Nossa crítica, até o momento, restringiu-se a tentar questionar a legitimidade da assistência médica fundada na compaixão. Mas se tentarmos generalizar essas observações (referidas ao vínculo individual existente entre assistente e assistido), para estruturas gerais comprometidas com o bem- 
estar social e com a saúde pública, deveremos rejeitar, do mesmo modo, toda intervenção fundada no conceito de piedade.

São dois os perigos decorrentes da extrapolação do sentimento de compaixão para o amplo mundo dos que sofrem. Primeiro, à medida que a piedade já não é um co-sofrimento silencioso que, assim como a compaixão, pertence ao âmbito do privado, no momento em que ela precisa ser enunciada e declarada publicamente, deve expor no âmbito do público aquilo que estava reservado para a intimidade do sentimento. Essa bondade que agora precisa ser obsessivamente declarada e insistentemente enunciada pode converter-se em seu oposto: na hipocrisia, na falsidade e na perseguição. Segundo, na medida em que se refere à massa dos fracos e se desvincula do cosofrimento privado, pode terminar glorificando essa mesma debilidade que é sua condição material de existência. Desse modo, o sofrimento, que é sua causa imediata, se pode converter em um mal necessário para que exista o bem.

De acordo com Arendt (1990), a partir da enunciação da piedade como virtude, os modernos estados benfeitores acabam por negligenciar o valor da liberdade. Foi assim como a Revolução Francesa finalmente assumiu como objetivo a abundância e não a liberdade. A partir dali o Estado moderno promete o fim do sofrimento e da escassez, porém, essa promessa não realizada fala de outra perda que não é reclamada: já não se procura criar instituições capazes de quebrar os vínculos coercivos que nos prendem aos outros.

De modo semelhante, Foucault soube mostrar como as instituições de assistência que, em nome da segurança, do bem-estar e da assistência aos necessitados, emergem após a Revolução Francesa, geraram mecanismos de controle e sujeição antes inconcebíveis. Em diferentes estudos genealógicos, a análise será levada até o limite de mostrar que esses novos saberes, preocupados com o bem-estar da população, como a assistência social ou o saber médico, constituem estratégias efetivas de poder. Para manipular aqueles sujeitos que fogem à categoria médico-jurídica de 'normalidade' e moldar sua vontade para fins precisos e socialmente eficazes, estes saberes sustentam-se em mecanismos coercivos, porém socialmente admitidos. 
Digamos, por fim, que o perigo, inerente a uma assistência pública que se apresente como piedosa, consiste em que, por trás da repetição da velha promessa sempre postergada de garantir o bem-estar geral, ela se contenta em reforçar a sujeição dos corpos, pela mediação das biopolíticas. Tanto o auxílio técnico-administrativo referido à pobreza, quanto uma assistência apta para cobrir as demandas de saúde da população devem rejeitar qualquer apelo à piedade e propiciar uma solidariedade efetiva entre iguais. A solidariedade, no momento que pressupõe a pluralidade humana, precisa da mediação do diálogo e da argumentação. Fica excluída, portanto, qualquer generalização que unifique a pluralidade dos que sofrem negligenciando sua singularidade e sua individualidade. Só assim poderemos assumir o lugar desse outro que sofre e que reclama o direito a ser assistido; desse outro que (mesmo quando seus interesses possam ser contrários aos nossos) reconhecemos como alguém que é nosso semelhante. Trata-se, enfim, de "colocar o respeito acima da compaixão" (Szasz, 1994:306), a solidariedade acima da piedade.

Privilegiar a solidariedade em detrimento da compaixão piedosa significa, simplesmente, privilegiar o diálogo em detrimento do monólogo. No primeiro caso, é possível e necessário ouvir as demandas e os argumentos daqueles que reclamam o direito de assistência. No segundo, se repete o monólogo compassivo do sujeito caridoso que imagina poder conhecer, sem ambigüidade, o sofrimento dos outros, como se se tratasse de seu próprio sofrimento. Neste último caso, a intervenção será pensada não em termos de direitos e deveres, mas sim pelo imediatismo de um 'amor aos que sofrem', que prescinde de qualquer argumentação fundamentada em razões.

Todavia, existe um outro motivo para privilegiar a solidariedade em relação à compaixão. Acreditamos que é possível afirmar que, enquanto a solidariedade faz parte do âmbito da ética e pode ser considerada como um de seus princípios mais desejáveis, a compaixão, em certos limites e circunstâncias, pode vir a se aproximar do âmbito da violência. Sabemos que, a partir da ética, se faz necessário falar de agentes racionais e livres, capazes de fazer determinadas escolhas e de se considerarem responsáveis pelas mesmas. Como afirma Marilena Chaú (1999), "A ação só é ética se realiza a natureza racional, livre e respon- 
sável do sujeito e se este respeitar a racionalidade, liberdade e responsabilidade dos outros agentes de sorte que a subjetividade ética é uma intersubjetividade socialmente determinada".

Só podemos falar de ética quando existem ações que envolvem sujeitos livres e responsáveis com um mundo constituído, por sua vez, por sujeitos livres e conscientes. A solidariedade, como princípio, não é outra coisa que a realização de ações que beneficiem os outros, a partir do reconhecimento do outro como um sujeito autônomo capaz de tomar decisões e de fazer escolhas, isto é, de aceitar ou de rejeitar essas ações. A solidariedade pertence ao âmbito da ética, a partir do momento em que só pode existir entre aqueles que se reconhecem como participantes de uma comunidade intersubjetiva de agentes morais. É por isso que uma assistência fundamentada na solidariedade, ainda que possa prescindir do 'amor pelos que sofrem', nunca poderá prescindir de uma preocupação desapaixonada por seus direitos. A legitimidade da mesma radica em que essa preocupação deverá estar marcada por uma intolerância radical contra tudo aquilo que já não pode mais ser tolerado: a violência, a crueldade, a miséria e a intolerância.

Uma assistência que se fundamente em uma ética da solidariedade, não em uma ética piedosa, precisará traçar estratégias reais e eficazes de resistência contra as diversas formas de violência atualmente existentes. Essas estratégias deverão ter a precaução de considerar a cada um dos beneficiários dessas açồes como seres individuais capazes de argumentação e nunca como partes da massa anônima e sem rosto dos 'necessitados'.

Se aceitamos que "a violência se opõe à ética porque trata seres racionais e sensíveis, dotados de linguagem e liberdade, como se fossem coisas, isto é, irracionais, insensíveis, mudos e inertes ou passivos" (Chauí, 1999), deveremos concluir que, enquanto a solidariedade refere-se a seres dotados de linguagem e liberdade, a compaixão pode vir, ao contrário, a reduzir esses seres à condição de coisas, de meios para a consecução de um fim. São eles que possibilitam a realização desses atos altruístas a partir dos quais muitas pessoas e muitas instituições podem ser, publicamente, reconhecidas como virtuosas e humanas. A existência da miséria e daqueles que sofrem com ela participam na criação de uma ficção de moralidade, em que sujeitos benfeitores se reco- 
nhecem entre si como agentes morais de uma pretensa comunidade intersubjetiva que não poderia ser considerada ética, pois encontra sua razão de existir na exclusão dos 'compadecidos'.

Por fim, assinalemos que, enquanto a solidariedade põe em evidência a existência do 'mal', pois significa a impossibilidade de aceitar ou tolerar aquelas situações que nos diminuem e nos violentam, a compaixão corre o risco de banalizá-lo. A compaixão apenas restringe-se a "estimular nossa tolerância ao intolerável". O mal se banaliza cada vez que acreditamos na possibilidade de uma assistência compassiva ou caridosa compensatória. Isto porque, como já foi observado, no século XIX, por De Gerando (1977:87), "a caridade é o meio pelo qual uma relação entre indigência e abundância se mantém basicamente justa". Também porque o compassivo tem o poder de escolher, dentre todas as misérias e violências cotidianas, as que merecem ser compensadas.

As instituições ou pessoas benfeitoras precisam denunciar e mostrar o horror dessas injustiças que merecem uma ação caridosa e, paralelamente, precisam minimizar o horror das misérias que não serão consideradas, isto é, banalizar esses males como sendo males menores. Qualquer tecurso pode ser eficaz para marcar a diferença entre o que merece e o que não merece compensação: "Uma estatística não faz chorar, e as grandes cifras da indigência são menos comovedoras que a visão de um homem ou de uma mulher destroçados pela carência e pela doença". É a esses últimos que à compaixão se refere, porém, no indigente não se percebe o homem, mas sim a indigência. Ele é fundamentalmente "uma mão tendida, uma ferida que limpamos, um organismo que reparamos. Ele é um homem, mas também é menos que um homem, pois está reduzido a suas necessidades biológicas. Nunca é um igual com o qual poderíamos iniciar uma relação de reciprocidade" (Bruckner, 1996:257). 


\section{0 Olhar Médico e a Tecnologia Pastoral}

Poder-se-á objetar que, até agora, ainda quando tentamos problematizar o papel da compaixão na assistência médica individual e na assistência coletiva, limitamos as referências e os exemplos a formas de auxílio e de cuidado dos pobres, que, em sua maioria, são quase que alheios a uma intervenção médica sobre a saúde dos necessitados. De fato, tanto o Hospital Geral quanto os asilos de pobres ou as workbouses são modos primitivos de prestar uma assistência, que, embora se diga caridosa, quase sempre prescinde do saber médico. O médico só se faz presente poucas vezes no mês e está subordinado às autoridades religiosas. Algo semelhante acontecerá tanto na Europa quanto no Brasil com os lazaretos, casas onde os leprosos tinham a obrigação de se confinar. Lá só podiam contar com o cuidado das religiosas ou, no caso do Brasil, das escravas criminosas. A figura do médico era secundária e pouco significativa (Machado, 1978).

Cabe, pois, neste segundo capítulo, atentar para o papel específico do saber médico da segunda metade do século XVIII até quase o final do século XIX. Resta saber como se produzem a transformação, o reforçamento, a desaparição e, enfim, a medicalização daquelas instituições de cuidado que praticamente prescindiam da figura e do saber médicos. Deter-nos-emos aqui na análise da emergência do hospital medicalizado e na transformação que vai da polícia médica à medicina social, e para isso recorreremos às análises de Michel Foucault e de Geotge Rosen. O objetivo é especificamente atentar para a persistência dessa lógica da compaixão que parece estar por trás dessas instituições que se propõem corrigir e disciplinar os corpos de todos os que fogem da 'normalidade'.

Acreditamos que Foucault, embora preocupado em estabelecer descontinuidades e rupturas radicais, pode nos auxiliar a compreender 
a persistência e continuidade de um discurso que não pode deixar de apelar para a piedade e a compaixão com os necessitados e os que sofrem, ainda quando as estratégias de intervenção tenham mudado radicalmente. Esta persistência se evidencia se atentarmos para aquilo que Foucault denominou de "poder pastoral".

Assim, se tomarmos como ponto de partida os estudos foucaultianos referentes à ética e, a partir deles, problematizarmos os estudos arqueológicos e genealógicos referentes à emergência do saber médico e dos biopoderes próprios da modernidade, constataremos que as análises das tecnologias do 'eu' e da tecnologia pastoral podem vir a ser um bom subsídio na compreensão de uma questão crucial: a persistência de uma moralidade fundamentada na obediência e na caridade, como sendo o complemento indissociável dessa racionalidade terapêutica, que se diz moralmente neutral e puramente instrumental. Essa complementaridade se evidencia quando pensamos que os filantropos de ontem e os serviços médico-assistenciais de hoje insistem em apresentar suas instituições disciplinares sob a retórica de um cuidado compassivo aos sofredores.

Para responder à questão da persistência de uma moralidade fundamentada na obediência e na caridade, é necessário interrogar-se sobre a aceitação dessas estratégias de poder e os mecanismos que fazem essas relações de poder legítimas e toleráveis. Acreditamos ser possível afirmar que o que historicamente possibilitou que essa coerção fosse tolerada é que ela sempre se apresentou sob a forma do humanismo e da compaixão piedosa. A oposição explorada por Foucault, em seus últimos textos, entre "cuidado de si" e "tecnologia pastoral", pode nos auxiliar a tematizar, de uma outra perspectiva, a questão que aqui nos ocupa: a de problematizar "o modelo de funcionamento histórico da medicina, para poder assim saber de que modo ela pode ser hoje modificada" (Foucault, 1990a:119).

Mesmo que a arqueologia do olhar médico fale do deslocamento da história natural à biologia (como referencial teórico privilegiado da anatomoclínica), mesmo que a genealogia nos situe nessa transformação que vai do Hospital Geral e do 'grande encerramento' ao hospital medicalizado e disciplinado, parece-nos que a tecnologia pastoral ainda é uma estratégia efetiva de poder, presente no nascimento da medicina moderna. 
As rupturas nem sempre são radicais e absolutas. Com efeito, o poder pastoral manifestava-se como uma tecnologia de controle própria das instituições assistenciais dos séculos XVII e XVIII, mas, longe de desaparecer no início da modernidade, integra-se e é reproduzido na gestão dos corpos e das populações, que é operada pelos biopoderes. Por isso, provavelmente podemos explicar as razões do convívio (no âmbito do 'saber médico') da tecnologia terapêutica com uma moralidade fundamentada na obediência. Seria importante lembrar aqui a distinção entre essas tecnologias que representam a matriz da razão prática: as tecnologias de produção; as tecnologias fundadas em sistemas de signos, que permitem a comunicação; as tecnologias de poder, que consistem na objetivação dos sujeitos; e as tecnologias do eu. Estas últimas

permitem aos indivíduos efetuar, por eles próprios ou com o auxílio de outros, um certo número de operações sobre seu corpo, sua alma, seus pensamentos ou suas condutas, obtendo assim uma transformação de si com a finalidade de atingir certo nivel de felicidade, pureza, sabedoria ou imortalidade. (Foucault, 1990b:48)

O problema em pauta situa-se na interseção das duas últimas tecnologias: o encontro do governo que os homens exercem sobre outros homens com o governo que os sujeitos podem exercer sobre eles próprios. Para analisar este processo, a que Foucault (1990) chamou de "governabilidade", é preciso considerar que o governo que os homens exercem sobre outros homens - seja o poder dos homens sobre as mulheres, dos adultos sobre as crianças, do saber médico sobre os sujeitos, ou da burocracia sobre a população - supõe uma certa forma de racionalidade, não é pura violência instrumental.

Nosso objetivo aqui é, portanto, analisar como se racionalizam esses biopoderes (essas modalidades de gestão e de administração, que se exercem sobre os corpos dos sujeitos e sobre as populações), que parecem partir da seguinte suposição: os corpos que ali são geridos têm a obrigação 'moral' de dizer toda a verdade sobre si, de enunciar e tornar público qualquer segredo. Existe, com efeito, uma incitação ou uma obrigação de falar sobre os próprios atos, as próprias condutas, o próprio corpo, uma obrigação que supõe certo conhecimento de si, que deve ser enunciado, mas que, no entanto, exclui uma obrigação simétrica daquele que está ali para ouvir. 
O 'regime político da verdade' aparece aqui invertido. O dever de enunciar a verdade, de falar, de procurar certa inteligibilidade parece ser prioridade dos que estão em posição de debilidade: os atuais ou virtuais doentes. No entanto, o dever de enunciar a 'verdade', de falar, de argumentar e tentar tornar inteligivel o que acontece parece não ser uma das obrigações fundamentais dos que detêm o 'saber científico'. O certo é que essa complementaridade entre a demanda - pela qual o paciente tem a obrigação de enunciar tudo a seu respeito - e o silêncio ou a falta de inteligibilidade que ele, muitas vezes, deve enfrentar parecem ser elementos historicamente constitutivos dessa racionalidade.

Essa estratégia que poderíamos chamar de "circulação da verdade e do segredo" é, precisamente, uma das funções da medicina tradicional (Foucault, 1994). Acreditamos que ela não pode ser inteiramente dissociada das outras - cuidar da moralidade, demarcar os desvios e respaldar as segregações -, pois todas parecem estar vinculadas à emergência da própria racionalidade médica. Assinalar essas funções não implica, no entanto, qualquer pretensão de retornar a uma 'higiene natural' ou a um 'bucolismo antimédico'. Significa, sim, acreditar que uma análise referida às condições históricas de sua emergência pode auxiliar a retificar este modelo.

\section{Poder Pastoral e Polícia Médica}

É preciso contestar a afirmativa de que no início do capitalismo a medicina se tornou essencialmente 'privada'. Segundo Foucault, não é legítimo falar de uma medicina individualista que, pouco a pouco, com o decorrer da modernidade, iria converter-se em 'medicina social'. "A medicina moderna é uma medicina social, cujo fundamento é certa tecnologia social do corpo; a medicina é uma prática social. Só uma de suas faces é individualista e valoriza as relações entre o médico e o paciente" (Foucault, 1990a:23). Porém, isso não implica afirmar que a medicina moderna sempre se tenha ocupado com o nível de saúde ou com o corpo (entendido como força de trabalho) dos sujeitos produtivos. 


\section{Com efeito, a medicina social}

não teve como primeiro objetivo a formação de uma força laboral, adaptada às necessidades da indústria que se desenvolvia nesse momento. Não é o corpo do trabalhador o que interessa a essa administração da saúde mas sim o corpo dos indivíduos que constituem o conjunto do Estado: a população. (Foucault, 1990a:25)

De fato, a medicalização do proletariado não foi a primeira meta da medicina social, mas sim a última. Sua preocupação inicial referia-se à forma de acrescentar o poder do Estado. Acreditou-se que a conquista deste poder estava diretamente vinculada a um crescimento da população.

Estimular esse crescimento, controlando-o para que não trouxesse conseqüências negativas no âmbito da saúde foi a tarefa que, no final do século XVIII, Peter Frank reservou para a 'polícia médica' - momento que assinala o início da medicina social.

Interessa-nos analisar quais são os vínculos entre essa noção de polícia médica - que, longe de ser uma idéia isolada e sem conseqüuências, se difundiu a partir da Alemanha até a Áustria, Itália, Grã-Bretanha, Estados Unidos e França e que foi usada por mais de um século, de 1779 até 1890 - e a persistência daquela modalidade de exercício do poder que Foucault denominou "poder pastoral".

Com o objetivo de tematizar esses vínculos, deter-nos-emos aqui para analisar algumas das características centrais dessa tecnologia de poder, características que só podem ser discutidas com referência e por oposição com as tecnologias gregas de "cuidado de si". Essa tecnologia que aparece com o cristianismo pode ser definida inicialmente como um peculiar jogo de verdade, que supõe a necessidade de uma obediência total como virtude. O conhecimento de si deve ser explicitado por meio da confissão, da aceitação institucional de uma autoridade ou da aceitação autoritária em matéria de verdade.

A pastoral cristã estabelece um novo jogo entre a vida e a morte, a obediência e a verdade, os indivíduos e a identidade. "Será com o cristianismo que o poder pastoral se reativa, desenhando o perfil de uma modalidade solícita (piedosa) de poder, que tem que conhecer as neces- 
sidades materiais de cada membro do rebanho, o que eles fazem o que vão fazer, e o que acontece na alma de cada um" (Morey, apud Foucault, 1990b:43). Os estados modernos surgiram do cruzamento entre dois modelos de relação: o da cidade e dos cidadãos e o do pastor e do rebanho. se como:

As três características centrais desse poder pastoral podem definir-

- Responsabilidade: diferente do pensamento grego, para o qual cada cidadão era imputável e responsável por suas ações, na pastoral cristã o pastor tem a função de garantir a salvação do rebanho, sendo responsável pelos indivíduos e suas ações. Existem fortes laços morais que vinculam o pastor ao rebanho, por isso o pecado de cada ovelha pode ser imputado ao pastor. Mas, ao mesmo tempo, no auxílio que dispensa, na salvação dos outros que possibilita, é o próprio pastor quem se beneficia, pois é esse cumprimento da obrigação que permitirá sua salvação.

- Obediência: de acordo com o pensamento grego, a obediência deveria ser assumida como um dever. Em As Leis, Platão fala da obediência dos cidadãos livres com relação aos médicos, o que só acontece se existem persuasão, entendimento e aceitação de que a conduta sugerida pelo médico pode ser benéfica. No poder pastoral, a obediência deixa de ser um meio, torna-se uma finalidade em si própria, uma virtude e um valor. Exige-se dependência permanente e completa, uma submissão pessoal a uma autoridade institucional. Segundo São Bento: "os monges não vivem segundo o livre arbítrio, seu voto é de submeter-se à autoridade de um abade."

- Jogo de verdade: está relacionado à direção de consciência e à 'hermenêutica de si'. Embora o exame de consciência estivesse presente no mundo grego (especificamente nos pitagóricos e estóicos), tratava-se de uma modalidade de autoconhecimento na qual se contabilizavam, a cada dia, os deveres cumpridos ou não cumpridos e se avaliavam os atos realizados. No entanto, isso nada tem a ver com obediência ou com aceitar ordens dos superiores. 
A direção de consciência, por sua vez, é própria da pastoral cristã. O pastor deveria saber o que estava acontecendo na mente de cada um, seus pensamentos, seus atos mais secretos, seus pecados. Para isso, era indispensável a existência de técnicas que, como a direção de consciência, estabeleciam um vínculo permanente entre o pastor e o rebanho, um olhar capaz de individualizar não só o que cada um faz, mas também o que pensa e deseja. Enfrentamo-nos, assim, com a 'hermenêutica de si', pois se trata da exigência de descobrir e enunciar a verdade em relação a si mesmo, com a finalidade última da 'renúncia de si', a que Foucault dá o nome de "mortificação", a pequena morte diária que permite garantir o acesso ao outro mundo.

O pastor é responsável pela existência material de seu rebanho como um todo e de cada uma das ovelhas. O rebanho lhe deve, conseqüentemente, obediência ilimitada. A obediência exige a aceitação das verdades que o pastor impõe como tais, mas também um conhecimento próprio como pecador e penitente, que deve ser enunciado sob a forma da confissão e como um modo de solicitar a penitência.

Mas, o que esse poder pastoral tem a ver com a emergência da medicina moderna? Ao discutir a relação entre o governo de si e o governo dos outros, Foucault, em diferentes conferências e cursos nos últimos anos, afirmava existir uma vinculação imediata entre as tecnologias pastorais e o nascimento dos novos estados modernos. Essa vinculação está centrada, de maneira privilegiada, nas teorias que analisavam uma instituição na qual os teóricos do século XVII depositaram suas maiores esperanças: a polícia. Ela deveria preocupar-se com todas as necessidades e os conflitos suscitados pela população. Ela teria de ser suficientemente capaz de impor sua autoridade, de se responsabilizar pelos cidadãos e de conhecer tudo o que acontecia: deveria controlar a religião, a moralidade, a segurança, as artes, o comércio, os pobres e a saúde.

Para que essa polícia pudesse funcionar adequadamente, requeriam-se governantes sábios, um conselho judicioso e um povo obediente e piedoso. Essa relação existente entre o Estado absoluto e os súditos reproduz a velha tecnologia de poder que tinha nascido da pastoral cristã. Juntamente com o nascimento do Estado moderno, se assiste "ao desenvolvimento de tecnologias de poder, orientadas aos indivíduos e 
interessadas em dirigi-los numa direção contínua e permanente" (Foucault, 1990b:98). Entre essas tecnologias, a polícia ocupa um lugar privilegiado, na medida em que ela se apresenta, ao mesmo tempo, como uma 'utopia' (uma administração que poderia englobar todos os aspectos do vivente), como um sistema de regras para garantir o bom desenvolvimento de uma instituição e como uma disciplina acadêmica da qual se ocuparam diversos teóricos, entre eles Leibniz.

Georges Rosen (1994:182) mostrou que o vínculo existente entre essa teoria da polícia e a "polícia médica" ideada por Peter Frank, "conhecido como pioneiro da saúde pública e da medicina social", é imediato. Cada um dos teóricos que problematizaram as necessidades da população e sua vinculação com a "polícia" (entendida como teoria e prática da administração pública) dedicou extensas reflexões sobre a necessidade dos cuidados que deveriam ser dispensados à saúde da população. Esses "esforços culminaram, ao final do século XVIII, com a monumental obra de Peter Frank sobre polícia médica" (Rosen, 1994:101). Embora isso não tenha implicado uma significativa mudança nas tecnologias de poder já existentes: “o povo, porém, não passava de ser objeto de cuidado governamental. Em matéria de saúde (...) o soberano sabia o que era melhor para seu povo, e, por meio de leis e medidas administrativas, lhe ordenava o que devia, ou não, fazer" (Rosen, 1985:47).

O Sistema de uma Polícia Médica Completa, de Frank, apesar de apresentar-se como um estudo minucioso, não contribui verdadeiramente nem para a instrução do povo, nem como guia para o trabalho dos médicos. Na verdade, a maior contribuição deve ser procurada em um nível mais minucioso e cotidiano, no âmbito das estratégias de poder que torna viáveis. Caracterizado por uma confiança excessiva na regulação legal e pelos "detalhes e minúcias de suas proposições", referidos à saúde pública e à higiene individual, "serve mais como guia para os funcionários, encarregados de regular e supervisionar, em benefício da sociedade, todas as esferas da atividade humana, até mesmo as mais pessoais" (Rosen, 1994:134).

As funções da polícia médica eram garantir a higiene das moradias, o controle de bebidas, alimentos e vestuário, a procriação, o casamento e a gestação, os imípostos para solteiros e para as mulheres solteiras, 
maiores de 16 anos, a assistência às crianças, a supervisão de instituições escolares, a higiene mental das crianças, a iluminação e o aquecimento das escolas, a dieta, as doenças dos animais, o destino da água e do esgoto, a limpeza das ruas e o destino do lixo; entre outros tópicos.

A polícia médica é então responsável pela existência material da população, como um todo, e de cada um em particular. Essa população lhe deve, conseqüentemente, uma obediência ilimitada, que exige a aceitação das verdades que os oficiais de saúde impõem. No entanto, requer também um conhecimento de si, de suas condutas, de suas ações, que deve ser enunciado, sempre que solicitado, sob a forma da confissão e como um modo de evitar uma punição.

É possível reconhecer aqui os três elementos que caracterizam o poder pastoral: a responsabilidade (neste caso dos governos e dos oficiais de saúde, sobre a existência dos cidadãos); a obediência (uma submissão permanente, pois cada ato e cada conduta são olhados como um bem para o conjunto da população); um jogo de verdade (que tem a ver com a aceitação de um saber como verdade indiscutível, e com a enunciação da própria verdade, daquilo que se é e do que se faz). É evidente que nos enfrentamos aqui com a utopia de uma administração "omnienglobante". Embora ela nunca tenha sido realizada do modo como foi projetada, embora só se tratasse de aspirações não cumpridas, achamos que é significativa sua persistência no tempo e sua extensão no espaço.

Parece que a insuficiência teórica de um saber médico débil (próprio do século XVIII) que está sendo permanentemente questionado, precisava, para poder existir, dessa tecnologia primitiva de poder que é a pastoral cristã. Se a obediência podia ser exigida, era na medida em que era apresentada como a contraface de um auxílio caridoso que o Estado pastor tinha a responsabilidade de oferecer. Obediência significava, então, a possibilidade de governar os indivíduos de modo contínuo e permanente. Para que essa obediência existisse, a população deveria tornar-se inteiramente transparente aos olhos dos supervisores; não poderia haver segredos. A aceitação dessas pautas gerais que visam a garantir o cuidado de todos, sua proteção, sua saúde, exige o cumprimento de normas, leis, disposições, de um conjunto de obrigações e mandatos, de um conjunto de decisões autoritárias em matéria de verdade. 


\section{Poder Pastoral e Nascimento do Hospital}

Se concordamoś com Canguilhem e Foucault na afirmação de que, até fins do século XVIII, os resultados científicos e terapêuticos da medicina foram nulos, que só então ela se libertou do estancamento em que se encontrava desde a época medieval, será necessário olhar esses fenômenos que determinaram o nascimento da medicina moderna. Para Canguilhem (1977), essa nova situação da medicina se deve a três fatores: uma atitude generalizada de ceticismo terapêutico; o advento da fisiologia como disciplina médica autônoma; e o fato simultaneamente institucional e cultural que significou o nascimento da clínica e a reforma hospitalar que instituiu.

Deter-nos-emos, aqui, na análise deste último item. A emergência do hospital não só possibilita o vínculo da clínica com a anatomopatologia (pela referência à análise dos sintomas e à observação dos tecidos), mas também estabelece um encontro entre o poder disciplinar e um saber médico orientado para o meio (água, ar, percurso da roupa branca, esgotos) e permite a vinculação entre duas modalidades de exercício do poder: o poder disciplinar e a tecnologia pastoral.

No momento em que o poder disciplinar ingressa no âmbito do saber médico, se faz possível a individuação dos doentes, pois, ao se dividir o espaço, pode ser feita uma observação contínua, permanente e individualizada. Paralelamente, se transforma o sistema de poder existente substituindo o pessoal religioso pelo médico, como autoridade absoluta. Organiza-se um sistema de registros completo, que faz do hospital não só um espaço de cura, mas também de aquisição de conhecimentos e de produção do saber.

Esse sistema de registros permite, por sua vez, a comparação entre hospitais e regiões e "possibilita a comprovação de fenômenos comuns a toda população" (Foucault, 1970a:173), fazendo com que a tecnologia disciplinar se possa orientar simultaneamente ao indivíduo e ao grupo, como objetos de saber e de intervenção terapêutica. Mas essa população de que se fala se restringe a poucos: "os ricos continuaram, por muito tempo, a receber atenção médica, inclusive cirúrgica, em casa. Os pobres, por sua vez, temiam a admissão no hospital, como se fosse uma sentença de morte, um estágio intermediário que terminava com 
um funeral miserável" (Rosen, 1980:364). Essa situação se manteve mais ou menos. estável por quase um século e meio, a partir de 1780-90, quando foram organizados os hospitais medicalizados, até a segunda década do século XX, quando a adoção da assepsia permitiu diminuir o número de mortes decorrentes de cirurgias e tornou o hospital aceitável, como instituição de bem social.

Pouco a pouco, no transcurso do século XX, os hospitais admitiram um número cada vez maior de pagantes em quartos particulares. Mas, como afirma Rosen (1980:370), "em sua organização e funcionamento, o hospital moderno, em seu início, ainda conservava muitas características de seu predecessor (o Hospital Geral). Tinha como objetivo primordial ajudar na manutenção da ordem social, assistindo os doentes necessitados". Embora tivesse muito a ganhar e a aprender com esses corpos sofridos - que se apresentavam como um espetáculo para o olhar médico -, os hospitais medicalizados caracterizavam-se, inicialmente, como instituições de caridade, de auxílio aos doentes pobres cujas famílias não contavam com as condições mínimas para desempenhar essa função. É preciso considerar que, ainda quando o hospital passou a ter como objetivo prioritário a atenção médica e se orientou por normas científico-tecnológicas, bem como por exigências de racionalidade, ainda se estruturava segundo estratégias que parecem conservar características do passado (Rosen, 1980:370).

Essas mesmas orientações caritativas, que continuam a reger a assistência e as ações sanitárias, devem ser procuradas no nascimento dos hospitais modernos. "Hospícios e hospitais são estações obrigatórias no trajeto da assistência generalizada. São verdadeiras bases de apoio de uma política de quadriculação difusa das famílias, e observatório privilegiado das espécies e das formas de indigência" (Collière, 1989:72).

O nascimento do hospital depende de um contrato tácito entre pobres e ricos. Um contrato a partir do qual se articulam "o hospital, onde se curam os pobres, e a clínica, onde se formam os médicos" (Foucault, 1987:125). Esse contrato caritativo, além de favorecer individualmente os benfeitores, pelo conhecimento das doenças que ali se produzem, possibilita uma proteção, para os mais ricos, dos perigos sanitários gerais que os pobres representam. 
O hospital, como instituição caritativa de assistência aos doentes pobres, atinge, ao mesmo tempo, indivíduos e populações. Os pobres se tornam objeto de conhecimento e de intervenções médicas, no momento em que suas dores se transformam em espetáculo que o olhar da clínica poderá compreender e utilizar em seu benefício. $O$ que não poderia ser realizado no leito dos enfermos honestos, no âmbito da atenção privada - pois deveriam ser preservados o nome e a reputação do médico poderá ser livremente realizado no hospital. Ali o médico pode liberar seu gênio e sua sede de saber. Define-se, assim, o que se pode considerar o problema moral mais importante suscitado pela clínica:

Com que direito se pode transformar em objeto de observação clínica um doente ao qual a pobreza obrigou a solicitar assistência hospitalar? Ele requer um auxilio do qual é o sujeito absoluto na medida em que este foi criado para ele; mas agora lhe é imposto um olhar do qual ele é objeto, e um objeto relativo, pois o que se decifra nele está destinado a um melhor conhecimento dos outros. (Foucault, 1987:125)

O hospital, esse espaço de cura e assistência, esse espaço preparado para amenizar o sofrimento, pode resultar em um espaço em que se evidencia o exercício da tecnologia pastoral. Ninguém pode ser curado fora da sociedade. Ainda menos os pobres, que só podem receber assistência pela mediação do saber, da piedade e dos recursos disponíveis aos ricos. Estabelece-se, então, uma espécie de contrato, em que a saúde do pobre passa a ser responsabilidade dos benfeitores. Esses doentes pobres são obrigados a retribuir, dentro de suas possibilidades, a assistência recebida, transformando-se em objeto de saber para os outros. "O que é benevolência em relação ao pobre se transforma em conhecimento aplicável ao rico" (Foucault, 1987:120).

Podemos observar que, segundo Du Lorenz (1789), esse contrato, na verdade, está absolutamente explicitado:

Dos dons benéficos que vão minimizar os males do pobre resultam as luzes para a conservação dos ricos. Ricos benfeitores, homens generosos, este homem deitado no leito que houvestes preparado, experimenta hoje uma doença, pela qual não tardareis em ser atacados vós mesmos. Ele se curará ou perecerá. Em um ou outro caso, sua sorte pode iluminar vosso médico e salvar vossa vida. (Du Lorenz apud Foucault, 1987:127) 
De fato, o doente do hospital poderia negar-se a ser objeto de ensino e instrução. Nesse caso, porém, demonstraria ingratidão, pois "gozaria dos benefícios que resultam da sociabilidade, sem pagar o tributo do reconhecimento". Aquele que é assistido, aquele que inspira na mente dos benfeitores e dos médicos essa "comiseração ativa, esse desejo ardente de dar alívio e consolo" pelo qual os homens sensíveis podem se reconhecer como sendo bons pastores, tem o dever e os meios para retribuir esse zelo compassivo que redundará em benefício para a ciência e será vital para os ricos (Foucault, 1987:126). Ele tem o dever da obediência por uma estrutura de reciprocidade que se estabelece no momento em que aceita o cuidado e a proteção, e que ingressa em um âmbito em que não pode existit qualquer segredo, em que primam os valores da transparência e da obediência.

O hospital medicalizado nasce como uma instituição responsável pela assistência aos doentes necessitados. Estes sujeitos lhe devem, conseqüentemente, uma obediência ilimitada que exige a aceitação das verdades e das demandas que os médicos impõem. Porém, exige também, de cada doente, um conhecimento de si, de seus sintomas, de suas dores, de sua história de vida, o que deve ser enunciado, sempre que se peça.

Mais uma vez, podemos reconhecer, no momento de emergência do hospital moderno, os três elementos que caracterizam o poder pastoral: a responsabilidade (neste caso, dos benfeitores, filantropos e médicos sobre a saúde dos cidadãos), a obediência (submissão permanente e disponibilidade absoluta, como retribuição), o jogo de verdade (relacionado ao espetáculo que os corpos doentes representam para o olhar clínico).

Falamos, até aqui, de um modelo que pertence ao passado, alheio ao hospital racionalizado e orientado por normas científico-tecnológicas. Mas, como afirma Rosen (1980:371),

este tipo de hospital ainda tem características derivadas de seu passado, que nem sempre são coerentes com seus objetivos e normas explícitos. Por este motivo, quanto melhor compreendermos como em um passado recente uma instituição antiga foi transformada de uma hospedaria para pobres doentes, em um centro médico para todos, com maior 
clareza, como cientistas, seremos capazes de ver o hospital e mais eficazmente nós, como práticos, poderemos contribuir para sua evolução.

Algo semelhante poderia ser dito a respeito da infantilizacão dos sofredores - o que, muitas vezes, acompanha a assistência e a medicina social e, como tentamos mostrar, parece fazer parte da história da assistência.

Talvez agora possamos entender por que, historicamente, as estratégias silenciosas e coercitivas que se exercem sobre os corpos são legitimadas como formas compassivas e piedosas de socorro e assistência. Acreditamos que não por ironia, mas por estrita complementaridade, os filantropos podiam insistir em apresentar suas instituições disciplinares com a retórica da compaixão. Ali, se pretendia modelar os corpos, multiplicar sua docilidade e sua força, mas, ao fazê-lo, pretendia-se incluir os 'desviados' sob um olhar médico, capaz de restituí-los ao mundo da sanidade e da normalidade. Uma normalidade em que, em virtude do socorro e da caridade, todos os homens pudessem se irmanar, libertando-se, assim, dessa 'repugnância inata' que o sofrimento de um semelhante produz.

Se descartarmos a existência de um maquiavelismo consciente que se prefere apresentar como compassivo, para poder exercer mais livremente seu poder; é possível que descubramos a existência de uma solidariedade não enunciada entre a tecnologia pastoral e essa racionalidade própria das instituições disciplinares, estruturada segundo parâmetros de urgência social e de bem-estar geral.

Este percurso pelo poder pastoral permite fundamentar e reforçar algo já antecipado quando falamos da lógica da compaixão. Como vemos, tanto a razão disciplinar quanto a tecnologia pastoral parecem partir da mesma certeza: atuar sempre em nome e pelo bem dos que dizem auxiliar. Ambas conhecem esse bem de um modo claro e distinto, mesmo antes de solicitado. Ambas prescindem de argumentos, excluem as palavras e silenciam qualquer diálogo fundamentado em perguntas e respostas razoáveis. A primeira, na medida em que substitui qualquer explicação pelas normas indiscutíveis que prescreve; a segunda, pela força do sentimento compartilhado que aproxima os ben- 
feitores responsáveis aos sofredores submissos sem precisar da mediação de razões.

Lembremos que, para Nietzsche (1984:\$338), o compassivo nada entende de razões. "O coração o manda socorrer e ele acredita fazê-lo melhor, quanto mais imediato for o socorro". Assim, se faz inevitável o apelo para o dever que o paciente tem de consentir, de "aceitar um conjunto de obrigações, de considerar certo número de livros como verdades permanentes, de aceitar decisões autoritárias, em matéria de verdade" (Foucault, 1990b:81). De aceitar, enfim, que não só se deve acreditar em certosprocedimentos, afirmações, tratamentos etc., mas também se deve demonstrar que se acredita e agir conforme estabelecido. $O$ certo é que todas - e cada uma dessas exigências - parecem derivar-se, imediatamente, dessa antiga tecnologia de poder, que Foucault chamou de "poder pastoral". Tecnologia que substitui as demandas gregas de cuidado, conhecimento e governo de si pelas virtudes cristãs da obediência, da abnegação e da aceitação de verdades institucionalmente estabelecidas. 


\section{Disciplina e Filantropia

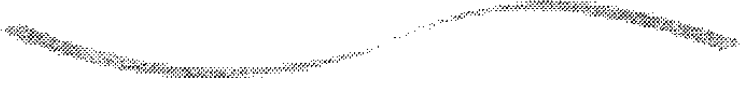

Analisamos, até aqui, a emergência histórica de um vínculo - nem sempre legítimo - entre uma ética fundada na caridade e na compaixão e uma assistência dirigida, prioritariamente, ao mundo da pobreza. Como vimos, a partir do século XVIII e cada vez com maior insistência, diversas intervenções públicas assumiram o controle desse mundo que representava um perigo ao mesmo tempo médico e jurídico. Assim, a passagem da antiga à Nova Lei de Pobres parece assinalar a passagem entre dois modos diversos, porém complementares, de intervenção. O primeiro, essencialmente compassivo, fundado na caridade e na punição; e o segundo, racionalista e utilitarista, fundado na exclusão e na normalização, que fará dessa pobreza 'perigosa' sujeitos docilizados e laboriosos submetidos ao imperativo de viver conforme o bem-estar geral.

Centrando-nos quase exclusivamente no pensamento de Foucault, pretendemos mostrar que é possível estabelecer certa complementaridade entre o tipo de modalidade política que adota uma ética intervencionista, fundada na caridade (a que Foucault chama de "poder pastoral"), e aquelas práticas concretas que se associam com o nascimento da medicina moderna; especificamente com o nascimento da clínica, a emergência do hospital medicalizado e a medicalização da força de trabalho.

A partir desta leitura é possível concluir que o poder pastoral e uma sociedade disciplinar estruturada segundo os parâmetros da ética utilitarista (preocupada com o bem-estar geral e com a urgência social) não parecem ser absolutamente estranhos um ao outro. Muito pelo contrário, e como já afirmamos, os filantropos do século XIX insistiram em apresentar suas instituições disciplinares sob a retórica da compaixão não por ironia nem por hipocrisia, mas por estrita complementaridade. 
Falamos de complementaridade, mas não de identidade. Será preciso então olhar para o espaço em que se evidenciam as diferenças, para aquilo que permite pensar em uma relação que não é estritamente analógica. É necessário especificar as diferenças essenciais entre duas figuras paradigmáticas, a do 'pastor' e a do 'filantropo'. Em outras palavras, temos de nos perguntar como se podem estabelecer as diferenças entre uma assistência que pretende se fundamentar na ética da caridade e aquela que parece ser decorrente do poder disciplinar.

Até aqui nossa análise centrou-se na crítica da legitimidade de qualquer modalidade de assistência médica, individual ou coletiva, que se pretenda fundamentar na ética da caridade. Mas agora passaremos a esboçar uma crítica dessa ética utilitarista que, a partir das teorizações de Jeremias Bentham, ${ }^{2}$ serviu como fundamento ético para as intervenções que os filantropos do século XIX dirigiram para o conjunto da população. De fato, para muitos autores, essa ética utilitarista clássica parece ser, ainda hoje, o fundamento tanto das instituições de controle, quanto das instituições de assistência médica e social.

Já falamos de uma solidariedade não enunciada entre a tecnologia pastoral e a racionalidade, própria das instituições disciplinares. Como Foucault soube mostrar em diferentes escritos, essas instituições respondem, de modo geral, às demandas da ética utilitarista tal como foi formulada por Bentham. Como podemos ler em Princíios da Moral e da Legislação ou em outros textos deste autor, a ética utilitarista se apresenta como inteiramente alheia a qualquer tipo de pensamento religioso ou teológico. No entanto, acreditamos que pode ser legítimo e frutífero analisar as estratégias e práticas efetivas que denunciam essa solidariedade, não enunciada nem admitida, pela qual a ética utilitatista e a ética piedosa podem ser pensadas como complementares.

Entre as estratégias a analisar, acreditamos que existe uma privilegiada. Talvez as analogias e as diferenças entre elas possam tornar-se manifestas e claras se examinarmos a participação na conformação e na emergência da família - instituição própria da nossa modernidade como agente privilegiado de medicalização. Quando se fala de controle

Limitamo-nos aqui ao utilitarismo benthamiano, difuso, que permeia as políticas filantrópicas. É preciso lembrar que o utilitarismo foi posteriormente objeto de reformulaçōes e precisões. 
da saúde coletiva ou de educação em saúde, não se pode deixar de pensar nas famílias como alvo e instrumento privilegiado desse controle ou dessa educação. Mas existe uma tendência que nos leva a esquecer que, para que a família, burguesa ou proletária, culta ou indigente, se constituísse em sujeito privilegiado de intervenções médicas, foi necessária uma longa história de temores, lutas e intervenções coercivas.

Finalmente, e só no século XIX, os Estados puderam pensar de modo efetivo em "governar através das famílias"; finalmente, a família medicalizada aparecia como espaço privilegiado no controle e na promoção da saúde coletiva. Mas a história nos ensina que essa função não faz parte de sua imaginada 'natureza', mas que ela é o efeito de intervenções e de estratégias pontuais e diversificadas. Nessa história vemos aparecer, entre outras, as figuras da mãe, do médico e do filantropo. Eles aparecem ora como aliados, ora como inimigos, mas cada um contribui a seu modo, e de uma maneira significativa e inadiável, na conformação da família medicalizada que é própria de nossa modernidade. Cada um deles aparece como a condição de possibilidade desse espaço eficaz de intervenção e de controle. E é na análise dessas estratégias pontuais que se pode evidenciar uma solidariedade, não enunciada nem admitida, entre ética piedosa e ética utilitarista, entre poder pastoral e poder disciplinar.

O percurso pelas estratégias e pelas práticas efetivas (que aqui será necessariamente parcial e limitado) deverá considerar prioritariamente as intervenções singulares que as políticas filantrópicas dirigem para o conjunto da população por mediação das famílias. Esta precária e parcial cartografia exigirá, porém, um esclarecimento a respeito dos vínculos existentes entre a ética utilitarista, conforme foi formulada por Bentham, e as intervenções efetivas dessas políticas filantrópicas. Talvez uma análise deste tipo possa auxiliar a tornar manifestos os limites de uma política assistencial, que parece estar historicamente associada a intervenções que ainda possuem um caráter de controle e de vigilância.

\section{Princíplos Utilitaristas e Políticas Filantrópicas}

Como afirma Chatelet, os saberes científicos fundados na experimentação e na observação, como a física ou a estatística, podem ser 
extremamente.úteis para os primeiros pensadores utilitaristas, pelo menos por duas razões. A primeira é por lhes permitirem operar com técnicas eficazes de controle e de gestão, que podem ser transferidas do âmbito da natureza ao âmbito das relações entre os homens. A segunda é que as experimentações e cálculos matemáticos podem dar às políticas, por eles implementadas ou estimuladas, "uma visão realista do dado social", pois "a referência à ciência aparece como um auxílio da ação política" (Chatelet, 1985:117), e, sem dúvida, uma referência privilegiada. Assim, para Bentham, os cálculos matemáticos são úteis para auxiliar na procura não só de leis físicas ou mecânicas, mas também de leis morais.

Surgiu, assim, uma invenção que atualmente parece impensável - a aritmética subjetiva -, que possibilitou uma aliança de valor inestimável: a aliança entre os cálculos matemáticos que nos falam da relação entre prazer e dor, felicidade e infelicidade, em um indivíduo determinado, e o coeficiente de sociabilidade, que indica de que modo as ações desse indivíduo em particular podem ter efeito na conquista, pela sociedade, do princípio utilitarista por excelência. Princípio esse que Bentham que definirá como "a procura da maior felicidade para o maior número”. Como afirma MacIntyre (1992:227), para Bentham,

diferentes fontes de prazer podem ser medidas e comparadas em relação com a intensidade e a duração da sensação derivada delas. Quando escolhemos diversas possibilidades a quantidade de prazer é o único critério: 'se a quantidade de prazer é a mesma, uma brincadeira de criança é tão boa quanto uma poesia'.

Segundo tal concepção, a felicidade coletiva só pode ser pensada como a soma das felicidades individuais no sentido específico da satisfação das necessidades de cada um, e todo e qualquer indivíduo tem um valor idêntico a uma unidade. Surge, então, uma dificuldade: como conseguir que cada homem tenha como meta a procura de uma felicidade individual que possa ser integrada nessa felicidade coletiva? Como evitar que os sujeitos realizem ações que, sem tender a acrescentar, diminuam esse bem comum?

Será necessário que a sociedade possa criar instituições capazes de controlar e regulamentar as condutas dos indivíduos suspeitos. Institui- 
ções não para punir, mas para corrigir; fundamentadas não no discurso jurídico e na força da lei, mas na capacidade 'ortopédica' e educadora das 'normas'. De fato, elas são aquelas instituições de controle que emergiram na modernidade e cuja função prioritária é a procura do bem comum: hospitais, reformatórios, presídios, asilos, casas de correção. Todas colaboram para atingir um mesmo objetivo: contribuir para a criação de "uma república democrática e filantrópica, no seio da qual a eficiência e a felicidade de todos sejam o produto de instituições que têm como tarefa medir e prever a conduta de cada um" (Chatelet, 1985:118).

Acontece que a ética utilitarista se caracteriza por ser um programa político de ação. Suas próprias premissas exigem que sejam idealizadas estratégias concretas de instrumentalização, e essas estratégias fazem parte das 'políticas filantrópicas'. O próprio Bentham foi um filantropo e um reformador social, pois era isso o que exigiam seus princípios éticos que são completamente refratários a qualquer utopia. O princípio da felicidade exige uma "regulamentação e uma vigilância universais". Inevitavelmente se o que se prioriza é, de modo manifesto, o bem geral, deveremos concluir que "o bem privado sempre necessita ser apreciado e bem orientado, para servir ao interesse comum" (MacIntyre, 1991:78).

Assim, todas as propostas políticas e legislativas de reforma idealizadas por Bentham partem de uma pressuposição: pode existir conflito entre o interesse público e o interesse privado, mas a tarefa das políticas filantrópicas e altruístas é orientá-los para que possam coincidir. Se isto é possível é porque se parte da afirmação de que a natureza humana pode ser 'modelada', porque se acredita que os seres humanos são maleáveis.

Mas, como já mencionamos, existe uma aritmética subjetiva que permite calcular as margens de dor e de prazer, que permite estabelecer que curso de ação terá conseqüências prazerosas e que ações devem ser evitadas. No entanto, e ainda tomando como ponto de partida a precisão matemática, é difícil entender qual é a abrangência que Bentham dá ao conceito de prazer e felicidade. Em outras palavras, sendo que a felicidade tem um sentido ambíguo e pouco preciso, cabe perguntar quais serão os critérios que permitirão fazer uma escolha entre esses cursos de ação. 
Dificilmente poderíamos responder a esta questão de um modo mais claro do que MacIntyre:

quando se referem à maior felicidade, os utilitaristas freqüentemente aludem a práticas e metas precisas de ação e não a conceitos gerais puramente teóricos. Estas metas são as do bem estar público e são metas particularmente importantes naquelas áreas de ação que interessavam a Bentham. Presídios e hospitais são campos nos quais é possível formular e responder adequadamente, ainda que com crueza, perguntas relativas ao número dos beneficiados e dos não beneficiados por algum curso de ação. Pois contamos com critérios óbvios estabelecidos a partir do sucesso ou do fracasso nessas áreas. Aumentará ou diminuirá a doença? Se for estabelecida esta penalidade aumentará ou diminuirá um certo delito? (MacIntyre, 1991:229)

Podemos concluir que a relação entre o utilitarismo benthamiano e as políticas filantrópicas ou altruístas não é acidental ou aleatória, mas sim essencial e necessária. Essas políticas derivam quase que logicamente das premissas utilitaristas iniciais. Contudo é preciso esclarecer que, embora o nosso interesse esteja centrado aqui na ética benthamiana e nas políticas do século XIX, parece que as mesmas críticas ainda poderiam ser reiteradas atualmente. Isto porque são esses critérios de bem-estar geral, de urgência social, de felicidade e interesse comum que governam e fundamentam, há quase duzentos anos, as mais variadas instituições de assistência pública, sejam elas referidas à saúde, à organização urbana, à educação ou à punição. E o certo é que, o fato de que ainda hoje o critério de bem-estar "possa parecer de forma tão indubitável o critério que deve ser levado em consideração em certas áreas de ação é, sem dúvida, algo que devemos a Jeremias Bentham e a Stuart Mill" (MacIntyre, 1991:229).

Se aceitamos a premissa de maleabilidade dos seres humanos, dificilmente poderemos fugir de um perigo que se associa ao conceito de felicidade, pois é então que ele se pode tornar moralmente perigoso. Afirmar que os homens são maleáveis é idêntico a afirmar que eles podem ser condicionados de modos diversos para agir conforme se deseja, e ainda se sentirem satisfeitos com sua sorte. 
Fundamenta-se, assim, a afirmação feita no início deste livro. Partimos da suposição de que existe uma solidariedade não enunciada entre a ética da caridade e a ética utilitarista. Podemos afirmar a respeito do utilitarismo o mesmo que enunciamos em nossa crítica às intervenções que se fundamentam na ética da caridade e da compaixão. Acontece que tanto a razão disciplinar quanto a tecnologia pastoral partem de uma certeza: sempre atuam em nome e pelo bem daqueles a quem dizem auxiliar, conhecem esse bem de um modo claro e distinto, mesmo antes de ser solicitado, e, tal como já assinalado, prescindem de argumentos, excluem as palavras e emudecem qualquer diálogo. A tecnologia pastoral, pela força do sentimento compartilhado que aproxima os benfeitores responsáveis dos sofredores submissos, sem precisar da mediação de razões; a primeira, na medida em que desvia e modela os interesses privados, através de normas e instituições inapeláveis, com a finalidade de orientá-las para a felicidade e o bem da maioria.

Aí reside a dificuldade desse conceito ambíguo de felicidade, justamente no fato de que ela pode ser um valor radicalmente incompatível com o valor da liberdade. Sempre é factível perguntar pelo preço que tivemos de pagar por essa felicidade. O certo é que "o conceito de maior felicidade para o maior número pode ser usado para defender qualquer sociedade paternalista ou totalitária, nas quais o preço pela felicidade é a liberdade dos indivíduos para efetuar suas próprias opções nessa sociedade" (MacIntyre, 1991:230).

Se é verdade que uma grande parte da assistência médica leva atualmente as marcas do utilitarismo, se é verdade que, juntamente com uma preocupação com o bem-estar geral, puderam se multiplicar estratégias de controle social e de restrição das liberdades (como afirmam autores como Ivan Illich, Thomas Szasz ou Michel Foucault), então acreditamos que a crítica que John Rawls dirige contra o utilitarismo não pode ser esquecida. Ele nos convida a substituir a suposta eficácia da ética utilitarista por uma ética fundada em uma clara concepção de justiça.

\section{A Crítica de John Rawls ao Utilitarismo}

A crítica de Rawls ao utilitarismo oferece um instrumento teórico eficaz para discutir este tema. A instrumentalidade de sua crítica talvez 
não resida exclusivamente no questionamento sobre o próprio conceito de justiça, mas sim na possibilidade de abrir as portas para pensar um outro modo mais justo de articular cada uma das partes, e de beneficiar ao máximo cada um dos membros que, de um ou de outro modo, participam de uma prática assistencial.

As perguntas que Rawls tenta responder são justamente as que nos interessam. Como atuar de um modo que possa ser considerado justo? Que podemos entender por justiça? Como estabelecer parâmetros capazes de garantir que uma prática possa responder às demandas de justiça? O que interessa não é tanto saber se tal ou qual profissional tem agido conforme a justiça, mas como estabelecer parâmetros capazes de fazer com que uma prática, seja ela qual for, possa ser considerada justa.

Em primeiro lugar, será preciso que nos proponhamos uma meta: eliminar diferenças arbitrárias e substituí-las, ao contrário, por aquelas diferenças que podem resultar absoluta e claramente significativas, diferenças em relação às quais não possam existir nem vencedores nem vencidos. Diferenças estas que sirvam, ao contrário, para garantir que através delas, todos e cada um dos participantes dessa prática sejam beneficiados. Rawls estabelecerá assim três princípios básicos, capazes de garantir o exercício da justiça, que se derivam de dois princípios fundamentais:

- Toda pessoa tem igual direito a um regime plenamente suficiente de liberdades básicas iguais, que seja compatível com um regime similar de liberdades para todos.

- As desigualdades sociais e econômicas têm que satisfazer duas propriedades. Primeiro, devem estar associadas a cargas e posições abertas a todos, em condições de eqüitativa igualdade de oportunidades, e segundo, devem procurar o máximo benefício dos membros menosprivilegiadosda sociedade. (Rawls, 1984:33)

Estes princípios se desdobram em outros três: a) o princípio de liberdade; b) o de igualdade de oportunidades; e c) o de diferença, que ordena beneficiar aos membros menos beneficiados do grupo.

O terceiro princípio, e sua ênfase no privilégio dos menos favorecidos, é que possibilita que as diferenças deixem de ser um dado mera- 
mente arbitrário e passem a ser elementos significativos, fundamentais no momento de organizar uma estrutura.

Enunciados esses princípios, cabe analisar a crítica de Rawls ao utilitarismo. Em primeiro lugar vejamos a concepção de justiça de acordo com o utilitarismo. Rawls (1984:31) dirá que "essa concepção assimila a justiça com a benevolência, e esta última com o programa mais eficiente para as instituições, conforme o objetivo de promover o bem estar geral. A justiça é uma espécie de eficiência". Muitas vezes, essa eficiência pode justificar instituições ou práticas contrárias àquilo que usualmente se entende por justiça. Com base nessa definição, a justiça de uma prática se transforma em uma questão de equilibrar entre vantagens e desvantagens, de calcular a respeito de qual seria o melhor modo de compatibilizar a satisfação dos interesses envolvidos, sem considerar se eles implicam ou não a aceitação de princípios que poderiam ser reciprocamente reconhecidos por todos.

A justiça entendida como imparcialidade eqüitativa pressupõe justamente o contrário, que existe um ponto de partida que nunca pode ser desconsiderado, o estabelecimento dos princípios que podem ser reconhecidos por todos e por cada um dos integrantes de uma prática. Conseqüentemente, nunca poderá ser considerado prioritário o benefício de alguns, se esse benefício implica que outros se sintam prejudicados.

Em relação à interpretação de base dos princípios de justiça, o utilitarismo clássico está errado. Permite sustentar, por exemplo, que (...) a escravidão é injusta fundamentando-se em que as vantagens do dono dos escravos, por si mesmo, não chegam a equilibrar as desvantagens que sofrem o escravo e a sociedade em geral. (Rawls, 1985:36)

Mas, se a escravatura não se tivesse mostrado ineficaz, se tivesse permitido maior satisfação dos desejos, poder-se-ia concluir que não estava errada. Como afirma Rawls, o fato de ser suficientemente propícia para o dono dos escravos não pode constituir uma desculpa em favor da escravatura, pois nunca poderá ter mais peso do que as desvantagens sofridas pelo escravo. O certo é que o "utilitarismo não pode dar razão ao fato de que a escravatura é sempre injusta" (Rawls, 1984:35). 
Pelo contrário, se partimos da justiça como eqüidade, a escravatura será sempre, e sob qualquer condição, considerada injusta, sendo que, para isto, só existe uma razão: existem na prática da escravidão princípios envolvidos que não podem ser reconhecidos reciprocamente como benéficos para todos.

Imaginemos agora uma sociedade escravocrata, em que seja preciso justificar certa tolerância, na medida em que é, por exemplo, uma forte herança do passado, que somente pode ser desarticulada paulatinamente. Imaginemos que deva ser tolerado que aqui e ali continuem existindo "privilégios que não deveriam ser concedidos" e que, no momento de fazê-lo, se termine por "relegar posições que não deveriam ser relegadas", com a única finalidade de ir quebrando gradativamente as raízes da estrutura, pois esse é o único modo para evitar matanças e catástrofes ainda maiores. Ainda assim, em circunstâncias de extrema necessidade, a escravidão nunca passaria a ser, na perspectiva de Rawls, uma prática “justa”, nem "justificável”. Isto porque os princípios de justiça têm um peso especial em relação ao princípio de maior satisfação dos desejos (ainda quando se trata do próprio desejo de viver). Os princípios de justiça não são contingentes, e é por isso que sua força é maior do que a que se deriva do princípio de efetividade.

A segunda crítica de Rawls ao utilitarismo se baseia na afirmação de que a justiça é, para a razão utilitarista, algo que se impõe aos sujeitos; algo que deriva de uma "eficácia executiva de um nível superior". Segundo esta concepção, a aceitação dos princípios de justiça não é mais do que o "resultado contingente de uma decisão administrativa de ordem superior, e a forma dessa decisão se considera semelhante à do empresário que deve resolver quanto produzir deste ou daquele produto, levando em consideração seu ganho marginal" Para o utilitarismo, a justiça parece assemelhar-se a "alguém que tem que distribuir bens a pessoas necessitadas, conforme a urgência relativa de suas necessidades" (Rawls, 1984:33-4).

Em todos esses casos imagina-se que devem-se aceitar os princípios de justiça porque eles são impostos, por uma pessoa ou por uma função abstrata de utilidade, a certos indivíduos que são alheios a esses princípios mas devem assumi-los, ainda que possam ser prejudicados, como os melhores e mais propícios. Neste ponto, o utilitarismo parece asse- 
melhar-se ao pensamento religioso. A imposição é estabelecida por mandados ou normas incontestáveis, que não falam diretamente de nós, de nosso presente, mas emanam de um nível superior e onisciente. Contrariamente aos princípios de Rawls que, como já dissemos, só adquirem validade na medida em que são reconhecidos, intersubjetivamente, por cada participante de uma prática comum.

Para garantir essa eqüidade, Rawls utiliza um artifício teórico que retoma a tradição contratualista e que pode resultar sumamente efetivo para problematizar as questões aqui discutidas. Ele imagina uma situação na qual um grupo de indivíduos racionais, porém egoístas, participam de uma prática comun. Esses indivíduos, pelo fato de serem racionais, têm clareza a respeito de seus objetivos e metas e podem estabelecer racionalmente certas prioridades, entre os meios que lhes permitem atingir tais objetivos. Eles desejam, mais do que qualquer outra coisa, conseguir esses objetivos, pois, sendo egoístas, privilegiam suas metas e não as dos outros membros do grupo. Entretanto, ao mesmo tempo, têm a virtude de carecer absolutamente de qualquer sensação de inveja (não desejam que os outros se prejudiquem para sentirem-se beneficiados).

Esta comunidade caracteriza-se por estar em uma situação peculiar. Nessa posição 'original' em que se encontram, lhes é impedido conhecer qualquer especificação a respeito de sua pessoa, assim como a respeito da pessoa dos outros, nada sabem da idade, posição social, raça, nível de instrução etc. Todos eles estão sob o mesmo 'véu de ignorância' que os impede de conhecer sua situação concreta. Tomando esses fatos como ponto de partida, os princípios adotados para o próprio benefício levarão necessariamente a privilegiar os menos favorecidos, assim como a prescindir de distinções arbitrárias que possam prejudicar qualquer sujeito do grupo, pois sempre existe a possibilidade de que o sujeito prejudicado seja eu mesmo.

Acontece que, como cada uma das pessoas é inevitavelmente egoísta, saberá concluir que, no momento em que o véu de ignorância seja levantado, no momento em que se possa sair dessa posição original em que as peculiaridades de cada um são conhecidas, quando as relações efetivas se mostrem, e se descubra, por exemplo, sua condição social menos beneficiada, se poderá gozar dos benefícios pactuados. Porém, 
se a condição econômica e social é favorável, então se poderá prescindir de tais benefícios, sem que isto signifique nenhuma perda significativa, pois não existiria verdadeira necessidade dos mesmos. De modo idêntico, a precaução de não salientar ou reforçar divisões arbitrárias, tais como as diferenças de raça, de sexo, de idade ou de qualquer outro tipo, aparece como uma garantia de eqüidade independente da condição racial, sexual ou etária de cada um dos participantes dessa prática.

É fácil observar que todos os participantes nessa prática tentarão excluir qualquer preferência por condições de trabalho escravo, pois ela só se pode fundamentar em princípios que prevêem benefícios somente para alguns. De igual modo, qualquer exclusão fundamentada em diferenças de sexo ou de idade, que eventualmente poderiam significar a própria exclusão, serão rapidamente rejeitadas.

No plano da assistência, estes princípios implicam uma democratização absoluta desse espaço, assim como das pautas de ação que regem as diversas instituições assistenciais. É que qualquer um pode se descobrir integrando qualquer instituição e em qualquer circunstância (como médico ou paciente, pobre ou rico, sábio ou ignorante). Assim, dificilmente aceitaremos fazer parte de sociedades ou instituições paternalistas, onde tenhamos de aceitar, como crianças obedientes, prescrições incontestáveis. Reconhecemos aqui um princípio completamente diferente do princípio de eficácia ou de felicidade da maioria que, para os utilitaristas clássicos, deve fundamentar qualquer decisão, incluídas aquelas que tratam de modelar as condutas das pessoas a fim de fazer com que, entre interesse público e privado, não exista contradição.

\section{Da Caridade à Filantropia}

A crítica de John Rawls pode nos auxiliar a refletir sobre o fato de que nem sempre o que aparece como natural ou evidente deve ser considerado como necessário ou obrigatório. Assim, como afirma Macintyre (1992), mesmo que os princípios utilitaristas possam parecer, até hoje, de uma forma tão indubitável, os únicos critérios que podem ser levados em consideração em certas áreas de ação, isto não significa afirmar que essa suposição não possa e não deva ser questionada. 
Falamos de uma solidariedade silenciosa e não enunciada entre esta ética utilitarista e a da caridade. Como já assinalamos, esta última serviu como fundamento para as políticas assistenciais fundadas no registro do 'dar' e do 'receber', no reconhecimento de uma complementaridade entre uma necessidade que pode ser satisfeita e uma gratidão infinita que se apresenta como o pagamento esperado por essa dádiva. Como vimos, ela serviu como fundamento a diversas formas de assistência aos necessitados durante o transcurso da época clássica, embora ainda permaneça durante grande parte do século XIX.

Historicamente é nesse momento que essa modalidade de assistência convive e se complementa com outra que surgirá então e que se tornará hegemônica: as políticas filantrópicas. Como já insistimos em diversos momentos deste livro, acreditamos que essa complementaridade se alicerça na exclusão de qualquer vínculo eqüitativo entre os sujeitos envolvidos, ou, como diria Rawls, na ausência de princípios que possam ser intersubjetivamente reconhecidos.

Tanto a ética utilitarista quanto a ética compassiva colocam os princípios acima dos sujeitos envolvidos. De acordo com estes modos de pensar, princípios religiosos ou de utilidade geral são os únicos que podem determinar, de modo claro e distinto, ainda antes de que seja solicitado, o que deve ser considerado um bem para essas pessoas a quem a assistência está destinada. A força dos argumentos, o diálogo fundado em questionamentos razoáveis, as decisões intersubjetivamente avaliadas são banidos pela prioridade conferida, em um caso ao sentimento de compaixão que nos unifica com a dor dos que sofrem, no outro, porque se estabelecem normas que possuem uma força ortopédica, capaz de prevenir os desvios.

Mesmo quando se podem assinalar tais analogias, é preciso reconhecer que se trata de duas modalidades diversas de fundar eticamente políticas assistenciais. Se nos detivermos na análise das diferenças, veremos que elas podem ser evidenciadas, mais do que nas teses efetivamente defendidas por seus teóricos (por exemplo, Bentham ou Rousseau), em uma mutação produzida no século XIX, na esfera das estratégias e práticas concretas de assistência aos pobres e necessitados.

Como já assinalamos, existiam, na época clássica, três formas de assistência diferenciada para os diferentes tipos de pobres: hospitais 
gerais e asilos, para os que não tinham família; donativos, para os mendigos; e organizações caritativas, para os 'pobres ignominiosos', aquela pobreza considerada 'digna', pois se tratava de pobres laboriosos que, por alguma circunstância particular, se viam obrigados a mendigar. Este tipo de assistência, que se exemplifica de um modo claro por referência à antiga lei de pobres, mostra rapidamente sua falta de eficácia. Ela aparece aos olhos dos reformadores como excessivamente onerosa e ineficaz. $O$ alto custo econômico e a falta de operatividade política se evidenciam em, pelo menos, quatro questões cruciais:

- administração geral desorganizada, centrada nas paróquias e extremamente difícil de controlar;

- falta de operatividade comprovada da dupla 'caridade humilhante-repressão', pelas dificuldades de exercer um controle sistemático sobre o uso das doações;

- falta de critérios gerais na atribuição de auxílios - não havia distinção entre velhos, jovens, crianças, mulheres ou homens;

- falta de critérios para diferenciar a pobreza daqueles verdadeiramente necessitados da dos pobres fictícios ou 'profissionais'.

Jacques Donzelot (1990:67), em A Polícia das Famílias, assim se interroga quanto ao caráter que essa mutação irá adotar:

O que não funcionava na antiga prática assistencial? Tudo: a natureza do que se dava aos pobres (donativo material), os critérios de oportunidade (que encobriam a percepção da pobreza), as formas de atribuição (que conduziam à alternância repressão-caridade legal). Os filantropos se propuseram a mudar tudo isso fazendo do estímulo à poupança a peça-chave de um novo dispositivo assistência, reforçando, assim, a família contra as tentações socialistas e estatais.

O problema que se apresenta, agora, diz respeito à substituição de uma forma de assistência onerosa e ineficiente por outra que consiga satisfazer as demandas utilitaristas - isto é, que contribua para assegurar o bem-estar da sociedade. Estas demandas se podem resumir na tentativa de achar um modo eficaz de assegurar o desenvolvimento de práticas de conservação e de formação da população, sem que isso possa ter efeitos políticos perigosos, garantindo ao mesmo tempo a domi- 
nação e a integração social. A princípio, poder-se-ia pensar que a filantropia teria condições para preencher tais exigências. Porém, é preciso reconhecer que a filantropia

não é uma fórmula ingenuamente apolítica de intervenção privada, na esfera dos problemas chamados políticos, mas sim uma estratégia deliberadamente despolitizante direcionada ao estabelecimento de serviços coletivos, na medida em que ocupa uma posição intermediária, entre a iniciativa privada e o Estado. (Donzelot, 1990:58)

Mas quais são essas estratégias pelas quais as políticas filantrópicas se diferenciam da assistência caridosa? Têm como base a inversão de dificuldades apresentadas por esta última, com a finalidade de tornar a assistência eficaz política e economicamente. Assiste-se então a uma inversão completa dos antigos códigos.

Inevitavelmente, será o próprio Estado ou as iniciativas pessoais, mas não as paróquias, que contam com o poder para organizar essa assistência, seja de modo formal, introduzindo um certo número de preceitos e conselhos - fazendo uso do aparelho de justiça -, seja através da instauração de um sistema educativo e sanitário.

As esmolas serão substituídas por conselhos. Os filantropos mudam radicalmente o caráter dos auxílios, já não se trata de dar aos necessitados bens materiais, mas bons conselhos:

Estabelecer entre as classes comumente chamadas inferiores e as classes superiores relações que não sejam as de dar, comprar, dirigir por um lado, e receber, obedecer, vender por outro (...). Nada mais excepcional que exercer sobre os pobres uma influência que não seja o resultado de um temor ou de uma esperança, mas no entanto é absolutamente necessário (...). O conselho é o ato que melhor indica a igualdade, pois resulta do desejo de influenciar de quem dá e da perfeita liberdade de quem recebe. Não é fácil fazer com que um homem pobre compreenda que as vantagens de um homem rico lhe dão não um poder material, mas sim uma influência moral legítima. (Donzelot, 1990:67)

Como vemos, as vantagens da nova assistência se apresentam como o reverso da anterior. Se os conselhos são melhores é porque não esta- 
belecem diferenças entre aquele que dá e aquele que recebe. Seria o caso de perguntar se seria tão óbvio assim inverter as personagens da história, se seria tão fácil assim achar que os pobres têm bons conselhos para dar aos ricos. Como tal inversão é obviamente impensável, o argumento da eqüidade desaparece. Restam então outros argumentos para essa elevação moral do conselho sobre os bens, argumentos estes que já não são eticamente legítimos. Em primeiro lugar, porque, obviamente, os conselhos são gratuitos, não representam nenhuma renúncia para aquele que os dá. Em segundo lugar, porque eles não podem ter efeitos perigosos. É impossível adquirir maus hábitos ou comprar bebidas com eles. E se é preciso dar algum tipo de auxílio material, ele terá a única funcionalidade de exercer uma influência moral sobre os necessitados.

Em segundo lugar, ficam estabelecidos critérios gerais e rígidos de atribuição dos auxílios. Estabelecer-se-á, assim, uma ordem de prioridades que situa a criança acima do velho, e a mulher acima do homem. As razões dessa mudança são facilmente entendidas. Um velho que está como que habituado a viver na indigência deve ter vivido grande parte de sua existência como um 'homem indigno'; as crianças, por sua vez, têm a possibilidade, assim, de virem a ser homens de bem, de serem modeladas conforme os interesses gerais. Será a figura da mulher que deverá receber esses conselhos como normas de vida a serem seguidas, tanto por ela quanto pela totalidade de sua família - a consciência de fugir dos bares e das bebidas, a necessidade de reter o homem no lar, é uma missão que ninguém pode desempenhar melhor do que a mulher. Está em suas mãos o fato de que a casa se transforme em um lar. Para isto, será importante que seja suficientemente grande, para contar com um quarto exclusivo para os pais, mas também suficientemente pequena, para evitar a permanência de hóspedes e visitantes, quebrando assim um velho sistema de solidariedades e auxílios populares.

Finalmente, será necessário que as novas políticas assistenciais possam controlar a existência de uma pobreza fictícia, que gosta de fazer da mendicância um modo de vida, alguns dos quais conseguem criar pequenas sociedades despóticas de exploração de crianças, chegando até a produzir artificialmente deformidades em seus corpos para 
que possam inspirar maior piedade, a chamada cirurgia teratológica. Mas também será necessário que, no que se refere aos verdadeiros indigentes, o auxílio prestado nunca seja maior ou similar ao que ganhariam se trabalhassem honestamente. Este requisito é indispensável para que não sintam uma 'falsa segurança', para que não possam concluir que é preferível depender de protetores a suprir suas necessidades com o próprio trabalho.

O deslocamento - que vai da modalidade caritativa de auxílios até a assistência filantrópica - estará centrado na necessidade de criar novas práticas de atribuição que permitam diferenciar claramente os verdadeiros e os falsos indigentes, mas que também possibilitem prever quais serão os fins dessa assistência, como serão usados os auxílios, sejam eles bens materiais ou conselhos. Será o Barão de Gerando quem explicitará essas práticas, em seu manual Le Visiteur du Pauvre de 1820, que será amplamente usado e difundido entre as mulheres consagradas, antecessoras das enfermeiras visitadoras e entre os filantropos (Collière, 1989; Donzelot, 1990). Segundo De Gerando, o melhor modo para controlar a utilidade de tal assistência seria a visita domiciliar: entrar na casa do pobre, ver como ele mora, o que come, com quem mora etc. Acreditava-se que somente dessa maneira se poderiam pesquisar as verdadeiras necessidades, desmascarando falsos indigentes, (por exemplo, mães desamparadas com crianças que na verdade não são seus filhos) e evitando a cumplicidade com os enganos.

Para De Gerando, somente entrando na vida do pobre, nas suas casas, seria possível realizar uma minuciosa pesquisa de suas verdadeiras necessidades. Seriam auxílios eficazes que permitiriam corrigir e endireitar as famílias, mas que também poderiam trazer à luz aquelas faltas morais que, segundo se imaginava, eram a causa das necessidades: "essa parte de negligência, de preguiça, de relaxamento moral que há em toda miséria"(Donzelot, 1990:71). É por isso que os higienistas podiam argumentar em uma dupla direção: "A imoralidade está no caminho da pobreza e da doença, mas a imoralidade pode resultar também da pobreza e da doença" (La Bergue, 1992:182).

Por fim, há que se estabelecer uma sistemática conexão das faltas morais com as necessidades econômicas. Isto é possível por meio de visitas freqüentes, vigilância contínua e continuada, e um instrumento 
que permita trazer à luz os detalhes aparentemente mais insignificantes da vida - uma 'cartilha' em que constarão detalhadamente os recursos econômicos da família, classificados segundo uma ordem de moralidadeimoralidade.

Segundo Donzelot, tais cartilhas não são inteiramente diferentes dos primitivos informes dos assistentes sociais, embora cem anos depois, em 1920, tenham sofrido algumas mudanças decorrentes de, na virada do século XIX, a assistência ter-se desvinculado das instituições que intermediavam o público e o privado e se transformado em assunto de Estado. O que acontecerá então é que os informes dos visitadores farão parte de uma rede ampliada, que contará com a solidariedade dos aparelhos administrativos estatais, da própria polícia e da justiça, que agora pode punir claramente esses desvios, seja intervindo nas famílias, seja tirando ou restituindo seus filhos. As novas regras ampliarão e especificarão novas táticas de intervenção.

Será feito, em primeiro lugar, um 'cercamento' da família a ser assistida, buscando informações junto a pessoas próximas - professores das crianças, vizinhos, parentes, chefes no trabalho, proprietários das moradias que alugavam.

Em segundo lugar, se procederá a um interrogatório das diferentes partes sem que uma tenha conhecimento da outra. Em um determinado momento se interrogará a mulher; em um outro, quando ela não estiver presente, o marido, de tal modo que possam ser confrontadas as respostas e evidenciadas as mentiras. Por fim, se permitirá que as pessoas falem livremente, em uma 'conversa franca' em que se darão os conselhos pertinentes. Esse será o momento de controlar a higiene da casa, a comida, observando tudo atentamente enquanto se deixa falar à vontade. Estas regras contribuirão para tornar ainda mais úteis as velhas cartilhas do Barão de Gerando. Agora se poderá descobrir, sem sombra de dúvida, quem pertence à categoria de indigentes honestos e quem integra a dos falsos, quem sabe usar corretamente os auxílios e os conselhos e quem escolhe prescindir deles.

Como vimos, as quatro deficiências assinaladas em relação à assistência compassiva serão rapidamente supridas pela assistência filantrópica. E é ali que radicam as diferenças centrais entre uma e outra. 
A filantropia já não pretenderá punir, reprimir, marcar as faltas nos corpos dos assistidos (lembremos a velha lei da letra P), ela já não está interessada na humilhação que produz a esmola ou na gratidão eterna que a sucede. Prefere, agora, dar conselhos eficazes e agir com o objetivo de prevenir e não de punir. Mas todos esses quatro elementos seriam absolutamente insuficientes se não analisarmos outro elemento que é seu complemento indispensável: o incentivo às famílias para a poupança como a única via de conquistar a autonomia. Acreditava-se que aqueles que não precisavam das visitas dos assistentes eram os pobres que tinham sabido ouvir os bons conselhos que falavam da necessidade de substituir as bebidas e as festas pela poupança. Os velhos costumes da 'santa segunda-feira', da distinção entre dias em que se trabalha para acumular e outros em que se folga para gastar, as tradições de consumir em festas o que sobrou do trabalho deverão ser substituídas pela poupança: "A lógica da poupança é sempre a mesma, reduzir as formas orgânicas, festivas, transfamiliares de solidariedade para evitar o perigo da dependência e o paralelo da insurreição" (Donzelot, 1990:68).

Pode-se deduzir do que foi dito que existe uma diferença substancial entre uma assistência fundamentada na caridade e outra, no utilitarismo clássico, e que tal diferença tem sua raiz na aceitação do pragmatismo. Todas as ações dos filantropos levam implícitas um cálculo pragmático de utilidades. Esse cálculo parece evidente se pensarmos na poupança como instrumento que possibilitava que, por sua vez, o Estado poupasse o dinheiro que antes investia (ou dilapidava, como muitos acreditavam). Também se evidencia na substituição de esmolas e donativos pela gratuidade dos conselhos e na hierarquia dos beneficiados, que deixa para um segundo plano os velhos improdutivos e os homens preguiçosos. Como afirma Guizart em 1824:

A caridade implica, sem dúvida, num maior sacrifício, porque sempre se apresenta ao espírito sob traços vivos e personificados, a filantropia que considera, de um ponto de vista mais amplo, os males que combate e o bem-estar que procura, está menos assistida pelos sentimentos de simpatia e de piedade. Um padre desce às celas e predica consolos. O filantropo, quando se ocupa dos presídios, é para estudá-los, para determinar sua finalidade (...); e as reformas que introduz, longe de ficarem só ali, se transformam tarde ou cedo em instituições. (apud Donzelot, 1990:70) 
As diferenças são claras e evidentes, a filantropia já não se fundamenta nesse intercâmbio simbólico que se estabelecia entre miséria e auxílio, em que a primeira, pelo único fato de existit, permitia evidenciar a bondade dos benfeitores, reforçando assim aissimetrias insuperáveis entre quem assiste e quem é assistido. O filantropo não é aquele 'homem compassivo' que, segundo Nietzsche (1978:\$133), "satisfaz uma necessidade de sua alma, fazendo o bem. E quanto maior for essa necessidade menos se posiciona no lugar daquele que socorre". O filantropo parece sentir a necessidade de falar de um intercâmbio simbólico aparentemente simétrico, ainda que as práticas e as estratégias por ele programadas reforcem claramente as assimetrias entre aqueles que estão moralmente habilitados para dar os conselhos e os que ainda precisam ser modelados conforme regras morais e econômicas benéficas para todos.

A genealogia das práticas assistenciais revela que, durante o século XIX, caridade e filantropia estabeleciam uma 'competência' da qual, como afirma Donzelot, sairá beneficiada a segunda. No entanto, achamos que essas práticas revelam uma solidariedade mais radical e profunda. Em muitos casos, por exemplo em relação à história do hospital medicalizado, elas demonstram-se complementares e solidárias. As duas estratégias tentam resolver um mesmo problema, encontrar um modo de assistir os necessitados sem apagar as assimetrias, a distância moral que separa os benfeitores e filantropos, de um lado, e os indigentes, de outro.

Naqueles espaços em que predomina a caridade, seja na assistência direta aos pobres tal como aparecia na época clássica, seja nos redutos que ocupará na modernidade (leprosários, hospitais de caridade ou asilos de órfãos), esse problema estava longe de ser uma questão política crucial, mais ainda se lembramos que, por exemplo para Malthus, a miséria podia chegar a ser pensada como um auxílio para eliminar sujeitos considerados indesejáveis. No entanto, como afirmou Chalmers, discípulo de Malthus, em 1840, as coisas tinham mudado significativamente.

Passaram os tempos nos quais, até certo ponto, se podia não levar em consideração o que acontecia nas classes inferiores e tranquilizar-se pensando em que sempre se podia recorrer a 
eliminá-las, caso viessem a provocar algum tipo de agitação; agora essas classes pensam, refletem, falam e atuam. É, pois, indiscutivelmente mais sábio e prudente tomar medidas legislativas, protetoras dos costumes e preventivas de um novo incremento dos abandonados, assim como outras medidas tendentes a tornar realmente úteis todos esses seres abandonados e capacitá-los para desempenhar um papel ativo. (apud Donzelot, 1990:74)

Com palavras que poderiam ser atribuídas a Bentham se explica a importância de modelar a consciência daqueles que aspiram à cidadania. Se eles querem falar e agir como cidadãos, deverão ser modelados conforme o que se espera de um cidadão. Os filantropos e suas políticas assistenciais fundadas nos bons conselhos serão os encarregados de modelar esses corpos. Eles sabem dizer de um outro modo, mas com a mesma clareza das assistências caridosas, qual é o bem daqueles a quem se diz assistir, e qual é o melhor modo de atingi-lo, pois filantropos e benfeitores conhecem esse bem de um modo claro e distinto ainda antes de que ele seja solicitado. E esse bem, é claro, coincidirá com uma vida disciplinada e laboriosa, que só se realizará plenamente no interior de uma família 'higiênica' e 'poupadoura'.

\section{A Família como Agente de Medicalização}

Em Vontade de Saber, Foucault fala de uma mudança ocorrida na família burguesa moderna. Até fins do século XVIII, com as mudanças políticas sofridas na Europa, a preocupação da grande família aristocrática, no que se refere a sangue e herança, desloca-se em favor de uma preocupação mais viva pela saúde, a longevidade, a procriação e a sexualidade dos que fazem parte da nova família reduzida e nuclear. As novas urgências econômicas demandam corpos mais treinados e conseqüentemente mais custosos, corpos que precisam de preservação e cuidado, pois o estado de sua saúde e a possibilidade de sua morte passam a fazer diferença. Dentre as instituições que tomam por encargo a medicalização dos corpos, existe uma considerada privilegiada, com importância maior do que o novo hospital terapêutico e que chega a ser, às vezes, seu suporte mais eficaz. Segundo explica Foucault, em Microfísica do Poder (1989:200), a família aparece, na sociedade moderna, como sendo o primeiro agente de medicalização: 
A política médica desenvolvida no século XVIII, em todos os países da Europa, tem como reflexo a organização da família, ou melhor, o complexo família-filhos, como instância primeira e imediata de medicalização dos indivíduos. Ela teve a função de articular os objetivos gerais, relativos à boa saúde do corpo social com o desejo ou a necessidade de implementar cuidados individuais. Ela possibilita a articulação de uma ética "privada" da boa saúde, (dever recíproco de pais e filhos) com um controle coletivo da higiene e uma técnica científica de cura, que é assegurada pela demanda dos indivíduos e das famílias.

A saúde e o bem-estar tornam-se, a partir do século XVIII, tema prioritário para o modelo familiar da época: a família burguesa. $O$ corpo saudável e limpo, o espaço organizado, purificado e arejado constituem os objetivos prioritários, as demandas sociais básicas referentes a esse grupo. É então que o jogo entre o 'cuidador' e aquele que é 'cuidado' passa a ser uma das leis morais essenciais da família. O certo é que essa preocupação sanitária adquire, pouco a pouco, e de um modo cada vez mais generalizado, um caráter moral. A pergunta grega referida ao bem viver desloca-se do público ao privado, do âmbito do político ao âmbito do doméstico. O bem viver pertence, agora, a esse espaço chamado de "lar familiar", sede da verdadeira felicidade. Mas é também nesse espaço onde se corporizam os deveres sociais essenciais. O lar transforma-se em um

meio físico denso, saturado, permanente e contínuo que envolve, mantém e favorece o desenvolvimento do corpo das crianças. Ele deve ser organizado como o meio mais próximo da infância, que garante sua sobrevivência e sua evolução tanto física quanto moral. (Foucault, 1989:1999)

A partir desse momento, a família passa a ser pensada como o núcleo essencial da sociedade, passa a ser hipervalorizada, tornando-se a estrutura privilegiada a partir da qual podem ser garantidas a educação, a assistência, a segurança e a felicidade de cada um dos sujeitos que compõem o corpo social.

Essas demandas higiênicas de cuidados com o próprio corpo e com o espaço familiar passarão para as famílias pobres como verdadeiras normas de moralização dos costumes e dos hábitos (La Bergue, 1992). 
A mãe se converterá, no transcurso de século XIX, em representante das demandas médico-higienistas no lar. Está em suas mãos gerar um espaço limpo, purificado e arejado - que é o outro lado de um cuidado com a moralidade da família. Como afirma Foucault (1989:201), lembrando um Informe do Conselho de Salubridade de França de 1830: "Ao induzir os deveres da higiene, não só se oferecem meios para reforçar a saúde, também se cumpre com um plano de endereçamento das vontades e de moralização das massas porque um povo amigo da limpeza também o é da ordem e da disciplina". A família burguesa moderna nasce, segundo Philippe Ariès, por volta de 1750, justamente no momento em que se produz uma suposta 'revolução do sentimento'.

Existem também outras razões muito mais fortes do que um novo sentimento pelas crianças ou pela morte que são determinantes. Estamos no momento de auge da teoria miasmática centrada na circulação dos fluidos. Paralelamente, se assiste a uma evidência que fala, pela primeira vez com números claros, da mortalidade das crianças: "Estatísticas de Rouen, França, durante o século XVIII mostram que, de três crianças entregues às amas-de-leite, uma morria antes dos dois anos (contra um quinto de óbitos em crianças cuidadas por suas próprias mães)" (Scliar, 1987).

A partir desse momento, as mães burguesas se vêem na obrigação de cuidar dos filhos, não mais deixando-os aos cuidados na nutriz. $O$ aleitamento passa então a ser favorecido, e terá, como grande apoio, a teoria dos fluidos. A mãe burguesa terá uma função central na sociedade: a conservação dos filhos. E isto em função de uma nova economia dos fluxos corporais pela qual Tisot (apud Donzelot, 1990:18) pode afirmar, em 1760, que: "a retenção do leite materno, que encontra sua saída natural bloqueada, se lança indistintamente em todas as direções e ocasiona múltiplos males. Também o desperdício de esperma pelo onanismo, esse azeite essencial cuja perda deixa aos homens fracos e alterados, gera doenças por todos conhecidas". Essas urgências sociais - vinculadas, fundamentalmente, à mortalidade das crianças - fazem com que se difunda, no século XVIII, a prática da medicina doméstica, que transforma a mãe em aliada indispensável do médico.

Assim, entre o último terço do século XVIII e fins do século XIX assistimos a uma proliferação de tratados, guias e dicionários de higiene, destinados à educação das mães, a fazer delas verdadeiras 'enfer- 
meiras domésticas' com conhecimentos sobre higiene do lar, medicação e cuidado das crianças. É assim como se apresenta, em 1876, o Dictionnaire de la Santé:

Proponho-me a ensinar às mulheres a arte da enfermaria doméstica. As veladoras mercenárias são as verdadeiras enfermeiras ou que as nutrizes de profissão são as mães: uma necessidade e nada mais. Tenho a ambição de fazer da mulher uma enfermeira perfeita, que compreenda tudo, mas que compreenda, sobretudo, que seu papel é esse: nobre e caridoso. O papel das mães e o dos médicos devem ser claramente diferentes. Um prepara e facilita ao outro; se complementam em interesse do doente. O médico prescreve, a mãe executa. (apud Donzelot, 1990:23)

Esta associação entre a medicina e a família, mediada pela mãe, possibilita que ela, e não mais uma estranha, seja responsabilizada pelo cuidado dos filhos. A mãe dispõe, então, de maior aceitabilidade social e de uma funcionalidade educativa que dispensam e anulam antigos hábitos vinculados com uma disciplina religiosa, em que tudo associado ao corpo era considerado mau e perigoso.

Por sua vez, a medicalização da família proletária responde a outras exigências que são, no entanto, similares. O problema não são tanto as amas-de-leite, mas o abandono das crianças nos hospícios. O uso do 'torno'- estrutura cilíndrica de madeira, aberta em uma de suas partes, que ficava na porta dos hospícios e onde eram deixadas as crianças não desejadas - possibilitava o anonimato e a ambigüidade do abandono. Por causa da alta mortalidade de crianças nos hospícios, esta nova técnica foi substituída, no início do século XIX, pelo sistema aberto, que exigia que a mãe declarasse os motivos do abandono. Ao mesmo tempo, promoveram-se novas formas de auxílio para que as mães, sobretudo as solteiras, pudessem cuidar dos filhos, sem terem de recorrer aos hospícios. Porém, exigiam-se o controle e a orientação dessas mães para conhecer a maneira como estes recursos eram efetivamente usados. Surgem, posteriormente, a partir de 1865 , as primeiras sociedades protetoras da infância, que ampliam o controle médico às famílias populares. Essas sociedades chegam a uma conclusão alarmante, porém, de certo modo, tranqüilizadora: 
nas classes pobres as crianças medicamente mais bem tratadas são as que dependem da assistência pública (...) as únicas crianças bem atendidas nas regiões pobres são as das mães solteiras, que conseguiram obter auxílios mensais e que estão sob a vigilância de um inspetor da prefeitura, a quem temem, e cujos conselhos devem ser ouvidos. (Donzelot, 1990:32)

A figura da mãe popular medicalizada não vai surgir então da leitura de textos médicos - já que a maioria era analfabeta -, nem da ingerência pessoal que o médico da família possa ter sobre ela - pois não existiam tais médicos -, mas da interseção entre assistência coletivavigilância médico estatal. Ainda que aparentemente se trate dos mesmos problemas a resolver - a conservação das crianças e o respeito aos preceitos da higiene -, as diferenças estarão em que já não se trata de assegurar proteção direta sobre essas crianças, mas de estabelecer um sistema de vigilância que, por intermédio das mães, se estenda a toda a família.

Embora a sobrevivência dos filhos seja central, existe outra função que a higiene outorga às mães, trata-se de uma função médico-moralizadora. É função da mulher tirar o marido da rua, fazer com que ele prefira o lar ao bar, a vida da família ao vagabundeio do alcoólatra, e, principalmente, fazer com que ele prefira a previsão da poupança à dilapidação das reservas em festas populares. Em fins do século XIX, a mulher popular recebe o instrumento que lhe permitirá cumprir esses objetivos: a moradia social. "Praticamente se tira a mulher do convento para que ela tire o homem do bar, dando-lhe uma arma: a casa, e um modo de emprego: excluir estranhos e tratar de que entrem o marido e os filhos" (Donzelot, 1990:42).

É assim que tanto a família popular quanto a família burguesa, por questões diversas mas solidárias, acabam reforçando uma coesão alicerçada em excluir o que é estranho. No caso da família burguesa, a coesão exclui os possíveis inimigos internos, os domésticos; no caso da família popular, exclui as tentações do exterior, os bares, a rua. As missões das mães também se diferenciam. A mãe burguesa descobre seu espaço no mundo da caridade e do 'missionariado', descobre que sua aliança com o médico pode ser estendida, pela sua mediação, às camadas populares e toma a seu cargo a educação higiênico-moralizadora dessas famílias. 
As mães populares, pelo contrário, não têm uma função de difusão, mas de controle do marido e dos filhos. Elas devem reforçar os vínculos internos e dissolver as solidariedades externas. Travam uma luta contra a falta de sanidade e a informalidade dos porões, como aliadas privilegiadas no trabalho dos higienistas. "Suas novas tarefas educativas são realizadas às custas da perda de coexistência com o campo social, de apartar-se de tudo o que a situava num campo de forças exteriores. Isolada, daqui em diante a família popular está exposta a que lhe vigiem seus desvios" (Donzelot, 1990:46).

A família popular ingressará, assim, no âmbito da 'vida privada', que até então lhe era inteiramente alheio e que, para muitas famílias populares, no resto do mundo, continuará sendo alheio ainda no século XX, pois é nas ruas onde a vida delas acontece, é nas portas das casas onde ocorre a sociabilidade. Ilustra bem este ponto a descrição de Sartre das ruas populares de Nápoles, em meados do século XX: "não existe nem dentro nem fora... onde o mundo exterior se vincula com o interior de maneira orgânica".

No andar baixo das casas se abriram um sem fim de pequenos quartos, que dão diretamente para a rua. Em cada um mora uma família. Os moradores utilizam esses quartos para tudo: dormir, comer, trabalhar em seus ofícios. Só a rua os atrai. Saem a ela para poupar o orçamento de luz das lâmpadas, mas também, eu acho, por humanismo, para sentir-se formigar entre os outros. Tiram as cadeiras e as mesas à rua, ao "umbral", metade dentro e metade fora, e é precisamente nesse mundo intermediário, que têm lugar os principais atos de sua vida, e também da sua história. Ontem vi um pai e uma mãe que jantavam fora, enquanto que o nené dormia no quarto. Quando uma mulher está doente e tem que ficar o dia todo na cama, o fato acontece a plena luz e todo mundo a pode ver. (Prost, 1991:34)

A vida privada nas famílias burguesas e populares não será a mesma, nem surgirá no mesmo momento. Assim, como afirma Perrot (1988:120), "se é certo que no século XX o operário dá mais valor à moradia do que à cidade, parece que no século XIX isso era ao inverso", pois para eles a vida transcorria na rua, na cidade. Basta lembrar das lutas operárias que giraram em torno da construção dos bairros ope- 
rários, e as sistemáticas lutas contra os preceitos dos higienistas, centrados em separar taxativamente o lugar de trabalho do lar, para eles indissoluvelmente ligados. A imagem de um abrigo obscuro e sem aberturas que obcecava os higienistas respondia, muitas vezes, a exigências inevitáveis, como poupar os impostos que, na época clássica, eram cobrados pela quantidade de portas e janelas, ter a suficiente umidade para conservar materiais ou ter um espaço bem aquecido no inverno. $O$ hábitat não era, para eles, o espaço onde viviam, realmente, mas sim um abrigo para passar a noite e preservar a autonomia.

Talvez por isso as famílias populares só destinavam ao aluguel uma ínfima parte de sua renda, que não ultrapassava $8 \%$. A preocupação dos higienistas com o ar puro e com os benefícios do isolamento, no lar familiar, não eram compartilhadas pelos trabalhadores obstinados em permanecer no centro da cidade. São evidências disso a ausência de banheiros individuais e o uso público de água que gerava espaços próprios de sociabilidade feminina.

Assim, no segundo inquérito parlamentar realizado na França em 1844, quando os operários foram convidados para depor, perante uma comissão, embora se queixem do estado das moradias de aluguel, não propõem a construção de banheiros particulares, já que consideram supérfluo. Muito mais importante é permanecer no centro de Paris, impedir que sejam excluídos da cidade. Na cidade eles encontram seus objetos de amor. Pensemos, por exemplo, em Jerom-Pierre Guilland, operário serralheiro, que defende seu direito de não ser afastado do "gosto distinto, puro e exigente das cidades" (Rancière, 1988:33). Ele e os seus querem perambular livremente pelas ruelas do centro de Paris, ficar perto dos teatros, das tabernas e das obras de arte. Os mais pobres dormem amontoados, mas podem lotar o teatro nos dias de apresentação gratuita, podem cantar e freqüentar a taberna. Disto se conclui que a sua aceitação ao confinamento do lar não será fácil, que a tarefa educadora e moralizadora dos higienistas e filantropos deverá saber procurar estratégias eficazes. Eles sabem, muito bem e "por própria experiência, que quando se lhes restringe a liberdade de circulação rapidamente aumentam os controles" (Perrot, 1988:124).

Como vimos, será a figura da 'mãe-higiênica' a que terá a função de tornar reais os sonhos dos higienistas. Como afirma Jurandir Freire Cos- 
ta (1989:225), "a mãe higiênica nasceu de um duplo movimento: por um lado, a emancipação feminina do poder patriarcal; por outro a 'colonização' da mulher, pelo poder médico". Essa colonização se dará inicialmente, tanto na Europa quanto na América, e tanto nas mães burguesas quanto nas proletárias, pela necessidade da resposta aos problemas da mortalidade infantil e da falta de cuidado das amas-de-leite com crianças sob sua responsabilidade. Insiste-se, então, no valor higiênico e moral do aleitamento materno.

Como tentamos mostrar, essa mesma prática médica teve efeitos diversos em um e em outro caso. Se o discurso médico dirigido à mãe burguesa abre a possibilidade de gerar espaços de autonomia e até de intervenção social, no caso das mães populares representa o perigo de uma intervenção não desejada em seus hábitos de vida, que segundo se diz, devem mudar radicalmente. Representa, enfim, o refinamento de mecanismos de controle e de vigilância que, já na época clássica, eram o outro lado da assistência.

Essa distinção nos fala claramente da eficácia da família como instituição, capaz de modelar os corpos e as condutas dos sujeitos, a fim de que seus interesses individuais possam coincidir com o interesse e com a felicidade do maior número. Nem os presídios, nem os hospitais, nem os asilos tiveram essa 'capacidade ortopédica' que a família garante, sendo ao mesmo tempo menos onerosa e politicamente menos perigosa. Sem dúvida, é essa eficácia que leva Comte a pensar que a família é o elemento último, ao qual pode reduzir-se uma sociedade, sendo por sua vez unidades irredutíveis. Para ele a sociedade é um todo orgânico, constituído por famílias e não por indivíduos, pois é a partir delas que as sociedades evoluem: " $\mathrm{Na}$ família, Comte busca não só a célula germinal em termos fisiológicos, a partir da qual se formam agregados maiores, mas também trata de encontrar nela os fenômenos propriamente sociais que se devem apresentar, tanto nos grandes agregados, quanto na própria família" (Arnold, 1991:57). A família que aparece como garantia da ordem e do progresso para Comte é a mesma que aparece como instituição corretiva e normalizadora para os filantropos e para os utilitaristas. 


\section{ConCLUSÃo}

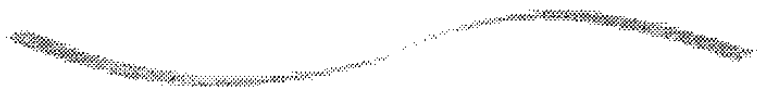

$P_{\text {ara concluir, tentamos estabelecer os motivos pelos quais as fa- }}$ mílias populares poderão aceitar e tolerar certos controles como a vigilância às mães solteiras, o deslocamento das moradias do centro para a periferia, as visitas e os interrogatórios dos higienistas, ou as exigências de transformar costumes e modos de vida. Se nos perguntarmos por que foi aceita a ingerência dessa dupla 'assistência-vigilância' como instância modeladora das condutas dos sujeitos, descobriremos que nem sempre se tratou de submissão a uma ordem de coisas não desejadas. Os novos padrões morais e a rigidez dos higienistas, dos filantropos e dos programas de assistência eram, na verdade, uma boa alternativa a velhas estruturas de poder essencialmente punitivas e opressivas, que pareciam estar destinadas a desaparecer.

Assim, se analisarmos o caso particular das famílias populares é possível que descubramos que, por trás da aceitação da poupança ou da internalização de um novo valor para a 'vida privada', existem pelo menos duas questões bem diferenciadas que precisam ser observadas. Se é certo que esses novos valores implicam a perda de pequenas solidariedades entre pares e que os espaços de socialização passam a ser programaticamente reduzidos, quebrando assim velhas alianças e conseqüentemente sua capacidade de resistência, é preciso reconhecer que essas novas exigências contribuem para a conquista dos objetivos explicitamente enunciados. Objetivos estes que sob nenhum ponto podem ser desconsiderados: diminuir a mortalidade infantil, reconhecer que é necessário dar solução da elevada taxa de mortalidade de crianças pobres, criar leis de proteção para as que trabalham e, por fim, criar uma legislação que possa garantir a escolaridade obrigatória. É preciso reconhecer que nenhum desses tópicos era considerado pelas antigas for- 
mas de solidariedade popular - que, aliás, nem sempre eram alheias a despotismos e opressões internas.

Tentamos mostrar até aqui que existem diferenças substanciais no modo de funcionamento da assistência filantrópica em relação às imposições brutais e às humilhações que pareciam ser próprias do auxílio caridoso. Mas, é preciso reconhecer que também existem diferenças substanciais na forma em que um e outro chegam a ser aceitos ou tolerados. Os conselhos e as normas preventivas dos filantropos e higienistas não são

administrados arbitrariamente por um poder que usa alternativamente a esmola e o látego, pois esses novos dispositivos aparecem como uma moeda da troca que constitui o fim de uma alternativa cotidiana a outra ainda pior. Se o discurso sobre a moralidade da poupança pode funcionar, isso não se deve, fundamentalmente (ainda quando foi o caso de empresas paternalistas), a que se tenha obrigado aos operários a depositar uma parte de seus escassos recursos nas cadernetas de poupança, mas sim ao fato de que por meio delas se obteve uma maior autonomia da família, em relação aos blocos de dependência e às redes de solidariedade, que apesar de tudo subsistiam. Se as normas higienistas relativas à criança, ao trabalho e à educação dos filhos puderam dar resultado foi porque elas ofereciam, tanto às crianças quanto às mulheres, a possibilidade de uma maior autonomia, dentro da família, com respeito à autoridade patriarcal. (Donzelot, 1990:61)

Resta esclarecer que o interesse aqui não foi traçar um percurso pela história da assistência com a pretensão de evidenciar uma sucessão linear de estratégias de opressão. Não pretendemos propor um retorno a formas pré-higienistas de assistência - o que parece ser o caminho escolhido pelas atuais políticas governamentais. Nosso interesse foi, sim, desnaturalizar essas estruturas que, como a família, têm a força da evidência. Mostrar que é possível reconhecer práticas e estratégias pontuais de produção e transformação das relações de poder - que nem sempre são eticamente neutras - nas instituições que, aos nossos olhos, parecem naturais e necessárias. Tais estratégias de produção e de transformação podem mostrar como estruturas aparentemente alheias ou contraditórias - pensemos na lei de pobres e na família, na assistência filantrópica e 
na caridade cristã, ou na ética utilitarista e no poder pastoral - não são inteiramente alheias umas às outras. Podem também evidenciar que, por trás das diferenças entre as estratégias de poder que sustentam a velha lei de pobres - aqui definida como poder pastoral - e aquelas estratégias próprias das instituições médico corretivas - aqui vinculadas com a ética e a política utilitarista -, parecem existir continuidades e persistências.

Como vimos, a complementaridade existente entre esmola e submissão, entre o cuidado caridoso e a aceitação passiva e grata pode ser garantida pela imposição brutal e arbitrária de punições que, no entanto, precisam conviver com espaços que se mantêm alheios a tais punições. Essa brutalidade se associa à porosidade de um poder oneroso e ineficiente que está longe de poder penetrar em todos os cantos da existência dos indivíduos, pois se funda na proximidade do sentimento compartilhado. Por outra parte, vimos que, ainda que o poder disciplinar possua a capacidade de penetrar em todos os cantos da existência, tendo em suas mãos a possibilidade de banir os segredos e as desobediências - superando, assim, a porosidade que caracterizava o poder da época clássica -, ele precisará de uma nova associação: aquela que se estabelece entre assistência e controles policiais, aquela que possibilita a associação e a complementaridade entre auxílio e vigilância.

Utilizando as análises de Foucault, tentamos mostrar, no segundo capítulo, a persistência do poder pastoral no âmbito da medicina social e sua convivência com a chamada polícia médica. Por fim, analisamos a complementaridade existente entre poder disciplinar, assistência filantrópica e o surgimento da família 'higiênica'. Resulta necessário assinalar que a família, como instituição de cuidado e moralização, vincula-se, por um lado, com as instituições herdeiras do utilitarismo, e, por outro, com regras e preceitos herdados do poder pastoral. Assim, as censuras que se multiplicaram no século XIX - que iam das bebidas ao onanismo, das festas às amas-de-leite e se dirigiam fundamentalmente à restrição da sexualidade fora do casamento - respondem ora a demandas higiênicas, ora a demandas religiosas. A figura da missionária burguesa - pensemos em Eugenia Grandet de Balzac - dificilmente podia prescindir do discurso religioso em sua prédica da moral higiênica. Certamente o poder pastoral já não retornará sem transformações para o discurso filantrópico. 
A higiene retomou a problemática sexual religiosa em outro estilo e com novos fins. Continuou a reprimir o prazer gratuito e irresponsável. Passou, porém, a exaltar a sexualidade conjugal, assinalando-lhe um papel nevrálgico na coesão do casal e na concretização do casamento modelo. (Costa, 1983:227)

Como assinalado em diversos momentos neste livro, não pretendemos falar de analogia, mas sim de complementaridade, de solidariedade entre dois tipos de discurso que se afirmam contraditórios.

As três características centrais do poder pastoral referem-se à responsabilidade do pastor por todos e por cada um, à obediência como um valor a ser atingido e, por fim, a um peculiar jogo de verdade que em torno da direção de consciência e da confissão. Assim, o pastor é o responsável pela existência material do rebanho como um todo, e pelas ovelhas, individualmente. Esse seu rebanho lhe deve, então, obediência ilimitada. A obediência exige a aceitação das verdades que o pastor impõe, mas também um conhecimento próprio como pecador, que deve ser enunciado sob a forma da confissão e como um modo de solicitar a penitência.

Esses elementos parecem reaparecer na polícia médica e no nascimento da clínica, mas onde talvez reapareçam de um modo ainda mais evidente é na própria instituição da família. A mãe higiênica garante a coesão da família, seu isolamento em relação às antigas solidariedades populares ou às intromissões das domésticas. Isto pelo uso de recursos que iam dos preceitos higienistas aos religiosos, de tal modo que nem sempre podiam ser diferenciados. A exigência de obediência, a responsabilidade pela existência de todos e cada um, assim como os recursos à direção de consciência e à própria confissão reaparecem, mas transfigurados.

A história da assistência entre os séculos XVIII e XIX pode ser lida como o despertar de uma nova consciência e de um sentimento humanitário, mas também como um espaço de apropriação e de transformação de antigas estratégias de poder. Nosso interesse foi analisar a persistência e a transformação desta antiga estrutura de poder que é o poder pastoral.

Pretendíamos olhar para os limites de uma assistência que se diz compassiva e que pela força do sentimento compartilhado - que aproxima cuidadores e doentes - reduz qualquer espaço de diálogo e de argumentação. Na ética da compaixão, assim como na ética utilitarista, 
se parte de uma evidência; se acredita conhecer, sem sombra de dúvida, aquilo que representa um bem para quem será assistido. E é em função desse conhecimento que se acredita ter uma responsabilidade absoluta, que exige como contraface uma obediência ilimitada, sem espaço para argumentos ou razões. Acreditamos ter mostrado que, na análise das práticas e das estratégias concretas de assistência, da lei de pobres até a família, passando pela polícia médica e pelo hospital medicalizado, existe alguma coisa que permanece por trás das mudanças e das transformações, algo que possibilita que fundamentos éticos divergentes e até opostos possam gerar estratégias e práticas complementares e solidárias.

Trata-se de estratégias e práticas que excluem a possibilidade de pensar a assistência em função de princípios que não sejam mandatos ou normas incontestáveis que emergem de um nível 'superior e onisciente'. E excluem, também, a possibilidade de fundar uma prática assistencial sobre princípios que só podem adquirir validade na medida em que são reconhecidos inter-subjetivamente por todos e cada um dos participantes envolvidos nessa prática. Princípios estes que, na medida em que devem ser partilhados, são alheios a qualquer demanda externa de submissão dos interesses individuais; seja em relação à aceitação passiva dos interesses do maior número, seja em relação à aceitação de preceitos já estabelecidos pela autoridade superior. Assim, as estratégias compassivas e disciplinares substituem e anulam os vínculos solidários entre iguais.

A pluralidade humana desaparece perante uma redução que só reconhece, de uma parte, a existência dos benfeitores, de outra, a massa informe dos 'necessitados'. "O escândalo ontológico da caridade (e da filantropia) é a desigualdade entre o doador e o beneficiário, quem, por ser incapaz de socorrer-se a si mesmo, só pode receber e agradecer, sem responder. Amá-lo por essa única razão significa exercer sobre ele, não nossa nobreza de alma, mas sim nossa vontade de poder" (Bruckner, 1996:261).

A solidariedade precisa, para poder existir, do respeito, da admiração, do reconhecimento do outro como alguém capaz de reclamar, aceitar ou negar assistência. A pessoa sujeita a uma necessidade não reclama ser protegida. Não quer nem o olhar piedoso, nem o isolamento: ela exige poder inserir-se em uma rede de vínculos em que seja reconhecida como um igual em orgulho e dignidade. 


\section{REFERÊNCIAS BIBLIOGRÁFICAS}

ARENDT, H. Vidas Politicas. Madri: Taurus, 1980.

ARENDT, H. Da Revolução. São Paulo: Ática, 1990.

ARENDT, H. Entre o Passado e o Futuro. São Paulo: Perspectiva, 1992.

ARENDT, H. La Condición Humana. México: Siglo XXI, 1993.

ARENDT, H. De la Historia a la Acción. Barcelona: Paidós, 1995.

ARIÈS, P. \& DUBY, G. Histoire de la Vie Privée. Paris: Seuil, 1985.

ARISTÓTELES. Ética a Nicómaco. In: Obras Completas. Buenos Aires: Aguilar, 1980.

ARNOLD, M. Sociedady Teoria de Sistemas. Santiago: Ed. Universitaria, 1991.

ARTETA, A. La Compasión. Barcelona: Paidos, 1996.

BENTHAM, J. Uma Introdução aos Princípios da Moral e da Legislaşão. São Paulo:

Abril, 1974. (Coleção Os Pensadores, v. XXXIV).

BENTHAM, J. El Panóptico. Barcelona: La Piqueta, 1980.

BERLINGUER, G. A Doença. São Paulo: Hucitec, 1988.

BERLINGUER, G. Questões de Vida. Londrina: Hucitec, 1996.

BERLINGUER, G. Etica della Salute. Milão: Il Saggiatore, 1997.

BERLINGUER, G. \& GARRAFA, V. O Mercado Humano. Brasília: UNB, 1996.

BOORSE, C. On the distinction between disease and illness. Philosopby and Public Affairs, 5:49-68, 1975.

BRAVERMAN, H. Trabalbo e Capital Monopolista. Rio de Janeiro: Zahar, 1981.

BRESCIANI, M. S. Londres e Paris no Século XIX: o espetáculo da pobreza. São Paulo: Brasiliense, 1982.

BRUCKNER, P. La Tentación de la Inocencia. Barcelona: Anagrama, 1996.

CANGUILHEM, G. El Conocimiento de la Vida. Barcelona: Anagrama, 1976.

CANGUILHEM, G. Ideologia e Racionalidade nas Ciências da Vida. Lisboa: Ed. $70,1982$.

CANGUILHEM, G. O Normal e o Patológico. Rio de Janeiro: Forense Universitária, 1990.

CAPONI, S. Georges Canguilhem y el estatuto epistemológico del concepto de salud. História, Ciências, Saúde-Manguinhos, 4(2):287-307, 1996. 
CAPONI, S. A compaixão no poder médico-assistencial. Cadernos Nietzsche, 4:63-82, 1998.

CASTEL, R. Da indigência à exclusão, a desfiliação. Rev. Saudelocura, 4:21-48, 1993. CHATELET, F. et al. História das Idéias Políticas. Rio de Janeiro: Zahar, 1985.

CHAUÍ, M. Uma ideologia perversa. Folha de S. Paulo, São Paulo, 14 mar. 1999. Mais!

COE, R. Sociologia de la Medicina. Madrid: Alianza, 1984.

COLLIÈRE, M.-F. Promover a Vida. Lisboa: Ed. SEP, 1989.

COSTA, J. F. Ordem Médica e Norma Familiar. Rio de Janeiro: Graal, 1989.

DE GERANDO. Le visiteur du pauvre: disciplines à domicile. Recherches, 28, 1977.

DEMO, P. Cidadania Tutelada e Cidadania Assistida. Campinas: Autores Associados, 1995.

DONZELOT, J. La Policía de las Familias. Valencia: Pré-Textos, 1990.

DUBY, G. Lección del pasado. In: Textos Para Pensar. Buenos Aires: La Noticia 1000, 1996.

FOUCAULT, M. Historia de la Locura en la Epoca Clásica. México: Fondo de Cultura Economica, 1967.

FOUCAULT, M. Vigilar y Castigar. México: Siglo XXI, 1979.

FOUCAULT, M. A História da Sexualidade I. México: Siglo XXI, 1980a.

FOUCAULT, M. La Verdad y las Formas Jurídicas. Barcelona: Ed. Gedisa, $1980 \mathrm{~b}$.

FOUCAULT, M. O Uso dos Prazeres. Rio de Janeiro: Graal, 1985.

FOUCAULT, M. El Nacimiento de la Clinica. México: Siglo XXI, 1987.

FOUCAULT, M. Microfísica do Poder. Rio de Janeiro: Graal, 1989.

FOUCAULT, M. La Vida de los Hombres Infames. Madrid: La Piqueta, 1990a.

FOUCAULT, M. Tecnologias del Yo. México: Paidós, $1990 \mathrm{~b}$.

FOUCAULT, M. La vie: l'expérience et la science. Dits et Écrits; 4, 1994.

GAUDEMAR, J.-P. La Movilización General. Madri: La Piqueta, 1981.

GORDON, R. A Assustadora História da Medicina. Rio de Janeiro: Ediouro, 1995.

HELLER, A. \& FEHÉR, F. Biopolítica. Barcelona: Península, 1995.

HIMMELFARB,G. La Idea de la Pobreza. México: Fondo de Cultura Económica, 1988.

ILLICH, I. A Expropriação da Saúde. Rio de Janeiro: Nova Fronteira, 1980. ILLICH, I. $\mathrm{H}_{2} \mathrm{O}$ y las Aguas del Olvido. Madri: Cátedra, 1989.

JASPERS, K. La práctica médica en la era tecnológica. Barcelona: Gedisa, 1988. 
LA BERGE, A. Mission and Method: the early nineteen century French public bealth movement. Cambridge: Cambridge University Press, 1992.

LANCETTI, A. A casa do inverno: notas para a desinstitucionalização da assistência social. Rev. Saudelocura, 4:71-84, 1993.

LE BRETON, D. Antropología del Cuerpo y Modernidad. Buenos Aires: Nueva Visión, 1995.

LÉONARD, J. Médecins, Maladies et Société. Paris: Sciences en Situation, 1992.

LEPENIES, W. Las Tres Culturas. México: Fondo de Cultura Económica, 1994.

LIS, C. \& SOLY, H. Pobrezay Capitalismo en la Europa Pre-Industrial. Madrid: Ed. Akail, 1984.

LUNARDI, V. História da Enfermagem: continuidades e rupturas. Pelotas: UFPel, 1998.

LUZ, M. Natural, Racional, Social. Rio de Janeiro: Campus, 1988.

MACHADO, R. Ciência e Saber. Rio de Janeiro: Graal, 1982.

MACHADO, R. et al. Danação da Norma. Rio de Janeiro: Graal, 1978.

MACINTYRE, A. Tras la Virtud. Buenos Aires: Ed. Cátedra, 1985.

MACINTYRE, A. Historia de la Ética. Buenos Aires: Paidós, 1991.

MARQUES, E. Da higiene à construção da cidade. Manguinbos, II(II): 51-67, out. 1995.

MILL, J. S. Sobre la Libertad: el utilitarismo. Buenos Aires: Orbis, 1985.

MOREY, R. Prefácio. In: FOUCAULT, M. Tecnologias del Yo. México: Paidós, 1990.

MUMFORD, L. La Ciudad en la Historia. Buenos Aires: Infinito, 1979.

NIETZSCHE, F. La Genealogía de la Moral. Valencia: Ed. Sempere, 1911.

NIETZSCHE, F. Aurora. México: Ed. Mexicanos Unidos, 1981.

NIETZSCHE, F. La Gaya Ciencia. Madrid: Sarpe, 1984.

PERROT, M. Os Excluídos da História. São Paulo: Paz e Terra, 1988.

PIRES, D. Hegemonia Médica na Saúde e a Enfermagem. São Paulo: Cortez, 1989.

PLATÃO. As leis. In: Obras Completas. Buenos Aires: Aguilar, 1980.

PORTER, D. Health, Civilization and the State. Londres: Routledge, 1999.

PROST, A. Fronteras y espacios de lo privado. In: ARIÈS, P. \& DUBY, G.

Historia de la Vida Privada. Buenos Aires: Siglo XXI, 1991.

RAWLINSON, M. Foucault's strategy: knowledge, power, and the especificity of truth. The Journal of Medicine and Pbilosophy, 12, 1987.

RAWLS, J. La Justicia como Imparcialidad. México: Ed. Unam, 1984.

RAWLS, J. Sobre las Libertades. Barcelona: Paidós. 1990. 
RANCIÈRE, J. A Noite dos Proletários. São Paulo: Companhia das Letras, 1988. RIBEIRO, H. O Hospital: bistória e crise. São Paulo: Cortez, 1993.

ROSEN, G. De la Policía Médica a la Medicina Social. México: Siglo XXI, 1985.

ROSEN, G. Uma História da Saúde Pública. São Paulo: Unesp, 1994.

ROUSSEAU, J: J. El Contrato Social: discurso sobre el origen de la desigualdad entre los hombres. Buenos Aires: Ed. Orbis, 1984.

RUPP, J. Michel Foucault, a política do corpo e a expansão da anatomia moderna. Rev. Pbysis, III(2), 1993.

SCLIAR, M. Do Mágico ao Social. Porto Alegre: LP\&M, 1987.

SZASZ,T. Herejias. México: Premia, 1983.

SZASZ,T. A Fabricaşão da Loucura. Rio de Janeiro: Guanabara, 1984.

SZASZ,T. A Escravidão Psiquiátrica. Rio de Janeiro: Nova Fronteira, 1986.

SZASZ,T. Cruel Compaixão. Campinas: Papirus, 1994.

THOMPSON, E. P. A Formação da Classe Operária Inglesa. Rio de Janeiro: Paz e Terra, 1987.

TURNER, B. El Cuerpo y la Sociedad. México: Fondo de Cultura Económica, 1989.

VEZZE'TTI, H. La Locura en la Argentina. Buenos Aires: Paidós, 1985.

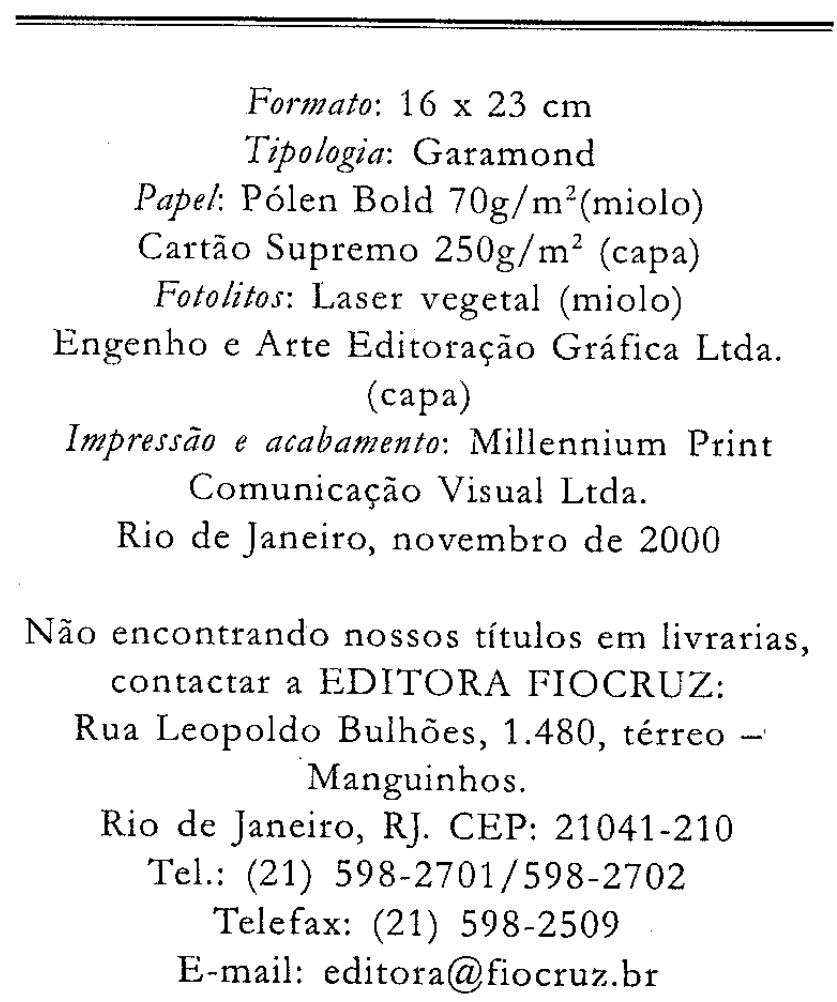

